\title{
PODPORA
}

směřovaná studentovi

se zrakovým postižením

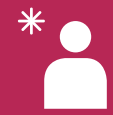

na vysoké škole

centrum podpory

studentů se specifickými potřebami

Hana Karunová 
Univerzita Palackého v Olomouci

Pedagogická fakulta

\section{Podpora směřovaná studentovi se zrakovým postižením na vysoké škole}

Mgr. Hana Karunová, Ph.D. 
Oponenti:

Mgr. Monika Smolíková

Mgr. Lucie Flekačová

Neoprávněné užití tohoto díla je porušením autorských práv a může zakládat občanskoprávní, správněprávní, popř. trestněprávní odpovědnost.

1. vydání

(C) Hana Karunová, 2020

(C) Univerzita Palackého v Olomouci, 2020

DOI: $10.5507 /$ up.21.24458359

ISBN 978-80-244-5835-9 (tisk)

ISBN 978-80-244-5836-6 (online: PDF) 


\section{Obsah}

Úvod. 5

1 Student se zrakovým postižením na vysoké škole................................. 7

1.1 Kvalita života studenta se zrakovým postižením ........................... 7

1.1.1 Být spokojený, být štastný.............................................. 8

1.1.2 Jak hodnotí studenti se zrakovým postižením kvalitu svého života coby vysokoškolského studenta?..... 10

1.2 Co znamená být studentem se zrakovým postižením na vysoké škole?

1.2.1 Obecné důsledky jednotlivých stupňů zrakového postižení

1.2.2 Konkrétní důsledky zrakového postižení ve vztahu ke studijním potřebám 15

1.3 Jak nejlépe komunikovat se studentem se zrakovým postižením?

1.3.1 Padlé mýty aneb komunikace se studentem s nevidomostí

1.3.2 Jak na chybné domněnky aneb efektivní komunikace s jedincem se slabozrakostí či zbytky zraku. 21

1.3.3 A další specifika komunikace se studentem na vysoké škole / univerzitě

2 Podpora poskytovaná studentům se zrakovým postižením na vysokých školách a univerzitách 24

2.1 Student se zrakovým postižením v Centru podpory studentů se specifickými potřebami 25

2.1.1 Výčet služeb

2.1.2 Př́ijemci a oblasti podpory 27

2.2 Knihovna pro uživatele se specifickými nároky.......................... 28

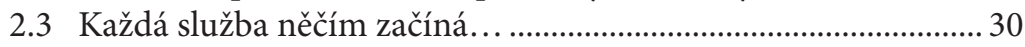

2.4 Obvyklý průběh a čerpání služeb ................................................. 32

2.5 Př́k lady z praxe ................................................................................ 34

2.5.1 Vzorový test a plnění zkoušky ............................................ 35

2.5.2 Změna oboru a akceptace postižení .................................. 35 


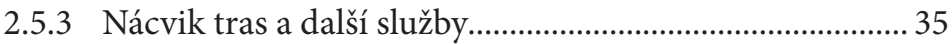

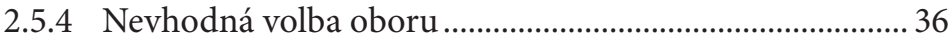

2.6 Návaznost na další instituce a spolupráce vysokoškolských středisek/center ................................................. 37

2.7 Koordinátor služeb a předpoklady pro výkon profese ................. 38

3 Pomůcky a student se zrakovým postižením na vysoké škole............ 41

3.1 Tyflopomůcky, tyflotechnika, asistivní technologie..................... 41

3.2 Ukázka vybraných tyflopomůcek a jejich využití .......................... 43

4 Digitalizace a zpř́stupnění textů pro studenty

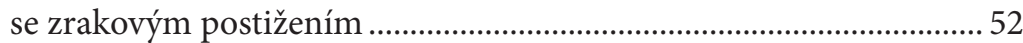

4.1 Služba digitalizace v rámci institucí............................................... 52

4.2 Specifikace digitalizovaného textu a legislativa .............................. 55

4.3 Proces digitalizace textů pro studenty se zrakovým postižením ................................................................. 56

4.4 Pracovník pro digitalizaci a předpoklady pro výkon činnosti ... 58

4.4.1 Pracovník koordinující digitalizaci, náplň práce a prèedpoklady pro výkon profese .......................................... 58

4.4.2 Asistent pro digitalizaci textů pro zrakově postižené uživatele.............................................................. 60

Závěr 62

Reference 64 


\section{Úvod}

Student se zrakovým postižením čelí na vysoké škole celé řadě výzev spojených $\mathrm{s}$ každodenním životem, at se jedná o samostatnost $\mathrm{v}$ rámci sebeobsluhy, prostorové orientace či zvládnutí požadavkủ studia samotného. Máte v rukou text, jehož posláním není vyčerpávající výčet všech způsobů podpory cílové skupiny, ale spiše vhled do možností podpory a pomoci studentům se zrakovým postižením v rámci vysokých škol a univerzit.

Nejdřive se čtenář seznámí se zkušenostmi cílové skupiny, tedy jak hodnotí studenti se zrakovým postižením kvalitu svého života coby vysokoškolského studenta. Dále bude řeč o důsledcích zrakového postižení a zásadách komunikace s člověkem se zrakovým postižením v prostředí vysoké školy. Poté se text zaměruje na otázku podpory poskytované studentům se zrakovým postižením na univerzitách, od výčtu nejčastěji poskytovaných služeb až po př́ílady z praxe. Následuje základní seznámení s pomůckami běžně využívanými studenty se zrakovým postižením v rámci studia. Poslední částí textu je digitalizace a zpř́stupnění studijních materiálů pro studenty se zrakovým postižením, kterému se s kolegou bliže věnujeme též v samostatném textu.

Pojetí knihy je koncipováno tak, aby zodpovědělo otázky studijních asistentů, vyučujících či intaktních studentů týkající se toho, jak usnadnit jedinci se zrakovým postižením studium na vysoké škole. Čtenář se může dozvědět více nejen o tom, jak podpora na vysoké škole vi̊či cílové skupině opravdu funguje v praxi, ale třeba též to, jak efektivněji pomoci. Předložený text není teoretickou studijní oporou, ale spiše souborem informací, které by měly být užitečné primárně pro praxi. Zmíněnou praxí je myšleno jak efektivnější zaučení studijního asistenta, tak podpora vyučujících, kteří mají studenta se zrakovým postižením ve výuce.

Souhrnně lze tedy říct, že snahou autorky, coby koordinátorky služeb pro studenty se zrakovým postižením, bylo zprostředkovat cást své práce také širšímu okruhu osob včetně těch, kteří se na službách poskytovaných Centrem podpory studentů se specifickými potřebami UPOL podílejí vyučujícím, studijním asistentům, kolegům ze studijních oddělení a spolupracujícím pracovištím. Samozřejmě ze čtenářů nevylučujeme samotné 
Úvod

osoby se zrakovým postižením, které se tak mohou více dozvědět o fungování centra, a to jiným způsobem než jen z webových stránek, ze dne otevřených dveří a podobně.

H. Karunová 


\section{Student se zrakovým postižením na vysoké škole}

Na úvod kapitoly se zastavíme u zrakového postižení, kvality života a důsledků zrakového postižení pro studium. Na závěr kapitoly si shrneme zásady komunikace se studentem se zrakovým postižením.

\subsection{Kvalita života studenta se zrakovým postižením}

Zrakové postižení můžeme pojímat jak v kontextu fyzického stavu zrakového analyzátoru a jeho funkcí, tak v rámci psychologické, sociální, ekonomické či hodnotově-duchovní sféry. Měla by nás tedy zajímat osobnost studenta se zrakovým postižením a všechny dimenze jeho života. Neměli bychom klást důraz pouze na otázku postižení či nemoci. Ačkoliv je pojem zdraví v odborné literatuře spojován $s$ kvalitou života, je toto téma specifické rozmanitostí pohledů a mnohočetností prrístupů.

Multifaktoriálnost kvality života zahrnuje kategorii fyzického stavu a funkční schopnosti, psychologického stavu a pohody, sociální interakce, ekonomického statusu aj. (Joyce a kol., 2013). Světová zdravotnická organizace vymezila kvalitu života jako jedincovo vnímání jeho samého, jeho života v kontextu kultury a hodnotových systémů, ve kterých žije, ve vztahu k jeho cílům, očekáváním, standardům či obavám (WHO, 2018). Student se zrakovým postižením na vysoké škole by tak měl pro pracovníka podpůrného centra dané vysoké školy, pro pedagoga i nepedagogického pracovníka působícího na pracovišti představovat holistickou bytost.

Když se budeme bavit o poskytování podpůrných služeb na dané univerzitě, pak nás tedy nezajímá jen zrakové postižení studenta, ale on samotný jako celek. I když je seznámení se s charakteristikami zrakového postižení, jeho stupni, způsobem komunikace s cílovou skupinou apod. důležitou součástí práce s takovým studentem. Níže v textu se budeme zabývat vymezením zrakového postižení a jeho jednotlivými kategoriemi ve vztahu ke studijním potřebám jedince.

Ještě než se dostaneme k definicím a kategorizaci, pojd’me se vrátit k tomu, co by mělo být hlavním cílem všech podpưrných služeb, a to je dosažení co 
nejvyšší kvality života, spokojenosti se životem. At̉ už se osoba se zrakovým postižením narodila, či o zrak přišla v průběhu života, nemusí daný jedinec hodnotit svou kvalitu života stejně. Dokonce ani individuální prožitek zdraví či obecně životní pohody nemusí nutně záviset na typu, hloubce či stupni postižení studenta vysoké školy. Ne každý student se zbytky zraku musí nutně oproti zcela nevidomé osobě hodnotit svůj život jako kvalitnější jen proto, že využívá zrak.

\subsubsection{Být spokojený, být štastný...}

A co může být společným jmenovatelem všech jednotlivých oblastí kvality života? Jednoduše lze hovořit o prožitku štěstí či spokojenosti. A právě těmito tématy se zabývaly např́klad Organizace spojených národů (United Nations) a jejich Světová zpráva o štěstí z roku 2012 (The World Happiness Report 2012) nebo Institut pro Zemi (The Earth Institute), fungující již 23 let v rámci Columbia University, a jejich Světová zpráva o štěstí z roku 2016 (The World Happiness Report 2016). Být spokojený, štastný a vnímat svůj život jako kvalitní souvisí podle Wikinga (2016) se schopností jedince vychutnávat si každodenní maličkosti, přítomný okamžik nebo umět přijímat a projevovat vděčnost. $V$ této spojitosti nás může napadat také otázka spokojenosti studenta se zrakovým postižením s poskytovanou podporou a pomocí ze strany vysoké školy. Avšak student by se měl aktivně podílet na službách jemu poskytovaných, neměl by je pouze pasivně přijímat. Spokojenost se službou tak nesouvisí jen s poskytovatelem, ale také se samotným uživatelem a mírou jeho aktivity, např́íklad při domluvě služeb. Na straně druhé stojí v rámci vysokoškolského vzdělání kromě poskytovatele podpůrných služeb (studijní asistence) právě pedagog. Možnost pracovat se studentem se zrakovým postižením ve smyslu vnímání této skutečnosti jako přínosné zkušenosti by měla stát na počátku každé spolupráce pedagoga s dotyčným studentem. Jak můžeme vidět, projev vděčnosti, spokojenosti a kvalitního života se nedotýká jen samotného studenta se zrakovým postižením, ale také všech zainteresovaných osob, které se podílejí na integraci studenta do běžného prostředí vysoké školy, univerzity.

Profesor psychologie z Kalifornské university v Davisu R. A. Emmons (2003) se zabýval otázkou vděčnosti v životě člověka, viz Objasnění výzkumného projektu zaměřného na vděčnost (volně přeloženo z originálu - 
Highlights from the Research Project on Gratitude and Thankfulness). Autor chápe vděčnost jako součást psychické a fyzické pohody. V rámci studie bylo prokázáno, že postoj vděčnosti má podstatný psychosomatický i sociální př́nos. Zhruba tisíc respondentů, kteří se zúčastnili jeho výzkumu, si vedlo tzv. deník vděčnosti (do nějž jedinci zaznamenávali okamžiky, za které byli ten který den vděční). $Z$ dlouhodobého hlediska prožívali účastníci výzkumu více pozitivních emocí, objevila se u nich větší chut do práce, měli kvalitnější spánek, vnímali zlepšení svého zdraví apod. Lze tedy doplnit, že mít každý den na mysli to, co činí život člověka smysluplným, má mimo jiné významný podíl na schopnosti vyrovnat se se stresem (Emmons, McCullough, 2003; Wiking, 2016).

Projekt realizovaný na Pedagogické fakultě Univerzity Palackého v Olomouci „Kvalita života osob se zdravotním postižením a osob pečujících“, IGA_PdF_2018_003, přinesl mimo jiné oblasti výzkumu zajímavou zpětnou vazbu ve vztahu ke službám poskytovaným studentům se zrakovým postižením na vysoké škole. V následující podkapitole si ve stručnosti přiblížíme výsledky projektu, který se vztahoval ke spokojenosti se službami i k tématu zrakového postižení a vysokoškolského studia (Michalík, Hrubešová, Pospíšilová, Karunová, Silberová, Haiclová, Majkusová, Vachalová, 2018).

V rámci uvedeného výzkumu si výzkumníci položili otázku: Jak hodnotí studenti vysokých škol se zrakovým postižením kvalitu svého života, primárně vzhledem k podpoře a pomoci poskytované vysokou školou? Pro sběr dat využili metodu dotazníku inspirovaného Dotazníkem kvality života Světové zdravotnické organizace: WHOQQL-BREF z roku 2004. Dotazníkové šetření probíhalo v rámci celé České republiky. Autoři vyšli z celkového předpokládaného počtu studentů se zrakovým postižením na vysokých školách (např́klad za rok 2010 to bylo 194 studentů, za rok 2016 jich bylo 189). V případě, že vycházíme ze skutečnosti, že na vysokých školách studuje v současnosti okolo 189 studentů se zrakovým postižením, úspěšnost sběru dat odpovídala rozmezí statisticky očekávaného rozpětí 10-15\% vrácených dotazníků. V rámci dotazníkového šetření byla návratnost $12,2 \%$. Celkem autoři pracovali se 46 vyplněnými dotazníky od studentů napříč vysokými školami v České republice, $\mathrm{z}$ toho bylo 23 výpovědí od studentů se zrakovým postižením a 23 ze skupiny intaktních. Zhodnocena byla také rizika a limity výzkumu včetně míry variability a reliability. 
Hodnoty reliability podle Cronbachovy alfy měly uspokojivý stupeň konzistence ( $\alpha=0,74$ u skupiny studentů se zrakovým postižením, $\alpha=0,70$ u intaktních). Hodnoty míry variability podle Fleissova kappa byly nízké ( $\kappa=0,032 \mathrm{u}$ studentů se zrakovým postižením, $\kappa=0,087 \mathrm{u}$ intaktních), ovšem i takto nízké hodnoty ukázaly, že se nejednalo o náhodnou shodu (tamtéž).

Uvedená data můžeme považovat za př́nosný průřez názorovou složkou studentů se zrakovým postižením na vysokých školách ve vztahu ke kvalitě života i životní spokojenosti. Více si uvedeme v navazující podkapitole.

\subsubsection{Jak hodnotí studenti se zrakovým postižením kvalitu svého života coby vysokoškolského studenta?}

Z uvedeného výzkumného projektu vyplynulo, že studenti se zrakovým postižením na vysoké škole vyžadují rozdílnou míru podpory v závislosti na osobnostních specificích jedince, jejich vlastním hodnocení kvality života, ale také hloubce a stupni zrakového postižení. Potěšujícím zjištěním byla skutečnost, že většina studentů se zrakovým postižením je spíše či plně spokojena se servisem poskytovaným vysokou školou. Skutečnost, že by jen zrakové postižení mělo vliv na hodnocení kvality života či samotného studia na vysoké škole, nebyla v plné míře potvrzena. Na tomto místě si uvedeme v bodech shrnutí prezentovaného výzkumu:

a) Téměř polovina ( $48 \%$ ) dotazovaných studentů se zrakovým postižením měla pocit, že je postižení přiměřeně omezuje v plnění studijních povinností. Př́mý vztah mezi zrakovým postižením a ztíženým plněním studijních povinností spatřovalo $17 \%$ studentů. Zrakové postižení může mít vliv na plnění studijních povinností, nikoliv však v takové míře, aby mohlo být považováno za alarmující. Stejný počet jedinců, kteří vyjádřili přímý vliv zrakového postižení na studium (17\%), je málo spokojen se svým zdravotním stavem.

b) Celkem $39 \%$ studentů se zrakovým postižením bylo málo spokojeno s tím, jak jsou schopni vykonávat studijní aktivity. Plně či téměř plně spokojeno bylo $44 \%$ respondentů. Přesto je míra nespokojenosti s nároky studia při zrakovém postižení poměrně vysoká, více než třetinová. Je potřeba brát v úvahu náročnost studia i specifické potřeby jedince. Kontrolní skupina vidících studentů byla v rámci výzkumu oproti 
studentům se zrakovým postižením spokojenější s kvalitou života na vysoké škole, a to o celých $13 \%$.

c) Co se týkalo podpůrných služeb poskytovaných vysokou školou, mohli jsme vidět, že studenti se zrakovým postižením byli většinou nebo plně spokojeni se službami podpůrného centra, a to téměř v $70 \%(69,6 \%)$. Ve více než polovině př́ípadů byli studenti se zrakovým postižením plně či převážně spokojeni s podporou pedagoga ( $65 \%)$. Podobně tomu bylo také s jejich spokojeností se vstřícností studijního oddělení (52\%).

d) V rámci př́istupnosti informací a orientace studenta se zrakovým postižením na univerzitě se bezpečněji v prostředí vysoké školy cítila kontrolní skupina vidících (74\%). Rozdíl u vidících jedinců oproti studentům se zrakovým postižením byl až o $22 \%$. U studentů se zrakovým postižením bereme v úvahu také otázku prostorové orientace a samostatného pohybu, nutnost naučit se určité trasy spojené se studiem, využívání průvodcovských služeb apod. Vedle hodnocení bezpečnosti prostředí jsme se přesvědčili, jak je to s orientací ve studijním prostředí při přechodu studenta se zrakovým postižením mezi budovami výuky, do menzy, na kolej apod. Jedinci se zrakovým postižením se obecně cítili s přesuny spokojeni až v $61 \%$. Pokud šlo o přechody z místa na místo $\mathrm{v}$ rámci bodů na trase spojených se studiem, tak v porovnání s intaktními se studenti se zrakovým postižením cítili opět o $22 \%$ méně bezpečně, o to zajímavější byly výsledky týkající se hodnocení mobility a orientace studentů mimo kolej či studentské bydlení. Respondentů se zrakovým postižením, kterým nečiní obtíže pohybovat se mimo studentské bydlení, bylo pro srovnání s intaktními jen $9 \%$. Většině studentů se zrakovým postižením dle jejich výpovědi dělá přiměřené potíže pohybovat se mimo kolej / studentské bydlení (65\%). Z daného vyplývá také vyšší závislost na podpůrných službách, potřeba průvodcovství a nácviku tras spojených se studiem.

e) Poslední podstatnou oblastí byla dostupnost informací, především pak studijní literatury. Studenti se zrakovým postižením byli až v $48 \%$ většinou či plně spokojeni s dostupností studijních materiálů. Částečná nespokojenost se však objevila až u $26 \%$, což není zanedbatelné ćíslo. Jeden jedinec se zrakovým postižením nebyl spokojen vůbec (Karunová, Vachalová, 2018). 
Jak můžeme vidět, informační deficit je jedním ze základních důsledků zrakového postižení. Právě dostupnost informací je podstatnou součástí podpůrných služeb a neměla by být opomíjena $\mathrm{v}$ rámci adekvátní intervence, at’ už se jedná o př́ístupnost míst, textů či studia obecně.

Podstatnou součástí všech služeb je rovněž propagace a informovanost, a proto na závěr uvedeme poslední zajímavé skutečnosti výše citovaného výzkumu. Součástí výzkumného dotazníku byla otázka, jak se studenti dozvěděli o podpůrných službách poskytovaných vysokou školou. Zhruba $35 \%$ respondentů se zrakovým postižením se o podpoře vysoké školy dozvědělo na internetu, $30 \%$ jedinců získalo informace během řešení úprav přijímacího řízení, na dni otevřených dveří na dané fakultě, kde nyní studují, a $26 \%$ prímo od pracovníků podpůrného centra / střediska, př́ípadně od vyučujícího. Jen $9 \%$ studentů se dozvědělo o službách přes spolužáky nebo přátele.

Při porovnání významnosti služeb, jak je v tomto ohledu hodnotí sami studenti se zrakovým postižením, zvítězila služba digitalizace studijních materiálů a knih včetně př́pravy zvětšeného černotisku. Na druhém místě se objevily předčitatelské služby, převod knih do Braillova písma, zapůjčení diktafonu, individuální konzultace a pomoc s vyřizováním studijních záležitostí. Co se týká nedostatku služeb, většina respondentů se zrakovým postižením neprojevila vyloženě názor, že by nějaké služby v rámci podpory chyběly (Karunová, Vachalová, 2018).

Co vše znamená být studentem se zrakovým postižením na vysoké škole a plnit povinnosti spojené se studiem či čelit výzvám běžného života? Na tuto a mnoho dalších otázek odpovíme v další kapitole.

\subsection{Co znamená být studentem se zrakovým postižením na vysoké škole?}

„Archetyp slepoty reprezentuje schopnost zahladit rozdíly mezi tím, co je známé, a tím, co není známé, mezi tím, co je zde, a tím, co není zde, mezi vnitřním a vnějším, konkrétním a obecným. Reprezentuje rozpuštění na pomezí bytí a nebytí." (Hull, 2012, s. 85). Archetyp slepoty či nevidomosti lze vnímat jako sociálně-psychologickou kategorii (tamtéž). 
Barash (2013) zdůrazňuje dějinný, historicky vývojový kontext a táže se, zda má porozumění nevidomosti svou historii a mění-li se v průběhu času pohled na to, co to je nevidomost? Postoj ke zrakovému postižení se podle něj odvíjí od toho, čemu lidé věří, co pro ně interpretace nevidomosti představuje. Jak dodává Majerová (2016), z takové perspektivy není osoba se zrakovým postižením pouze číslem, pojmem či definicí, ale je živou bytostí, přičemž neměnnost stavu nebo situace zrakového postižení se stává otázkou postoje, př́stupu či interpretace.

Dodejme, že student se zrakovým postižením představuje součást interpretace skutečnosti toho, kým je z pohledu interpretace pro univerzitu, vysokou školu a pracovníky, kteří s ním přicházejí do kontaktu. Zároveň v souladu s humanizací pojmosloví hovoříme na prvním místě o člověku, osobě, studentovi a až na druhém místě zmiňujeme zrakové postižení. Jak upozorňuje Majerová (2016), odborník by měl volit správná slova v psaném textu i v mluveném projevu. Každé slovo má emotivní, myšlenkový náboj, přičemž na jedince podle jeho zkušeností působí odlišně. Není tedy maličkostí skutečnost, jaké použijeme pojmosloví vzhledem ke studentovi s postižením zraku. Co se týká terminologie a účelu jednoduchosti písemného vyjádření, můžeme jako vhodné spatřovat použití pojmu student se zrakovým postižením, s nevidomostí, slabozrakostí, se zbytky zraku, s poruchami binokulárního vidění. Zmíněné potvrzují Finková, Ludíková, Růžičková (2007), když píší o jedincích s jednotlivými stupni zrakového postižení v rámci speciální pedagogiky osob se zrakovým postižením. Coby vhodné se jeví rovněž opisné výrazy, které tolik neoznačují - člověk ve stavu snížené funkce zrakového analyzátoru nebo člověk v situaci ztráty zraku (Majerová, 2016).

Pojd’me se blíže seznámit s jednotlivými kategoriemi zrakového postižení a se specifiky, která s sebou daný stupeň zrakového postižení nese.

\subsubsection{Obecné důsledky jednotlivých stupňů zrakového postižení}

Otázka praktičnosti kategorizace pro účel podpory studenta se zrakovým postižením na vysoké škole je pro nás klíčová. Zapátrali jsme v zahraničních zdrojích a našli jsme v rámci jednoho z francouzských slovníků (v originále Le dictionnaire du handicap) pohled, že žádná z kategorií není 
uniformní, at se již dotýká sféry edukace, mezilidských vztahů, nebo jiných oblastí. Ve vztahu k potřebě úprav a rozměru běžného života studenta se zrakovým postižením uvádí slovník následující členění, my jsme si jej upravili podle potřeb vysoké školy / univerzity (upraveno podle Zribi, Poupée-Fontaine, 2011):

a) Lehké zrakové postižení: jedinec je schopen fungovat v běžném životě $\mathrm{s}$ jednoduchou podporou, např. brýlemi.

b) Zrakové postižení střední závažnosti: nutnost využití jednoduché podpory, např. lupy.

c) Závažné zrakové postižení: osoba využívá zbytky zraku se speciálními pomůckami, objevuje se pomalejší tempo zrakové práce a větší unavitelnost.

d) Hluboké zrakové postižení: projevuje se schopností provádět denní aktivity s pomůckami a nutností využívat ostatních smyslů (kompenzačních faktorů).

e) Totální/úplné zrakové postižení: v rovině totálního zrakového postižení je osoba nucena využívat kompenzační činitele ve zvýšené míře.

f) Totální/úplné postižení zraku s nutností využívat v maximální možné míře ostatních smyslů - kompenzačních činitelů.

Domácí speciálněpedagogická odborná literatura se dále vyjadřuje k jednotlivým skupinám osob se zrakovým postižením, a to vzhledem $\mathrm{k}$ důsledkům nevidomosti, slabozrakosti, zbytků zraku a poruch binokulárního vidění. Právě toto pojetí vystihuje specifika, s nimiž je třeba efektivně zacházet $\mathrm{v}$ rámci speciálněpedagogické praxe, a budeme se tedy dále zmiňovat o důsledcích zrakového postižení pro studenta s tím daným stupněm zrakového postižení:

a) K důsledkům nevidomosti lze podle odborné literatury řadit následující: senzorický a informační deficit, informační bariéra; narušení vývoje poznávacích procesů, paměti, myšlení, řeči, představ a senzomotoriky; využívání vyšších kompenzačních činitelů téměř při každé aktivitě; specifika v rámci prostorové orientace a samostatného pohybu; úprava podmínek výchovně-vzdělávacího procesu, limitovaná volba povolání a pracovního uplatnění; vliv na sociální kontakt, oblast partnerských vztahů; specifika v oblasti psychického života člověka.

b) Podobně je tomu u důsledků slabozrakosti a zbytků zraku, které se mohou vyznačovat těmito znaky: senzorický deficit, informační bariéra, nepřesné vnímání předmětů, jejich detailů, barev, písmen, číslic, 
nepřesnost představ; narušení vývoje poznávacích procesů, podobně jako u nevidomosti; snížená koncentrace, slabší pozornost, pomalejší pracovní tempo; ztížená prostorová orientace, samostatný pohyb a sebeobsluha; důležitost úpravy podmínek výchovně-vzdělávacího procesu, limitovaná oblast volby povolání, pracovního uplatnění vzhledem ke zrakovému postižení; vliv na sociální kontakt, oblast sociálních vztahů; větší sugestibilita, horší adaptabilita, možné pocity méněcennosti.

c) Poslední oblastí jsou důsledky poruch binokulárního vidění, které zahrnují: narušení zrakového vnímání v rovině analyticko-syntetické činnosti; lokalizace a hloubkové, prostorové vidění, pomalejší utváření představ, nepřesnost; pomalejší a méně přesné motorické reakce na zrakové podněty; unavitelnost, slzení a pálení očí; pocity méněcennosti z důvodu nerovnocenného postavení očí, kdy se jedinec může snáze stát terčem posměchu (Stejskalová, 2012).

Níže se v textu posuneme od obecné roviny tématu ke konkrétním př́íkladům, právě ty nás zajímají především.

\subsubsection{Konkrétní důsledky zrakového postižení ve vztahu ke studijním potřebám}

Všechna výše uvedená specifika jsme dále analyzovali ve vztahu k požadavkům vysokoškolského prostředí. Podíváme se na prŕklady z praxe, s nimiž se denně setkáváme v rámci poskytované podpory.

a) Důsledky zrakového postižení a vysokoškolský student s nevidomostí:

- Senzorický a informační deficit, informační bariéra: nemožnost číst černotisk u skutečné a plné nevidomosti, u osob s praktickou nevidomostí může být $\mathrm{v}$ omezené míre zrak při zapojení speciálních pomůcek ještě využíván, záleží na povaze postižení zraku.

- Narušení vývoje poznávacích procesů, paměti, myšlení, řeči, představ a senzomotoriky: např́klad pokud jedinec ztratil zrak později v dospělosti a při učení byl zvyklý využívat vizuální cestu zapamatování si učební látky, bude se muset přeorientovat na kompenzační činitele jako sluch (audionahrávka přednášky, předčítání, odečítač obrazovky) či hmat (braillský text, čtení skrze braillský rádek připojený $k$ počítači). 
- Využivání vyšších kompenzačních činitelů téměř při každé aktivitě: s tímto se dále pojí unavitelnost a náročnost studia. Vydržet plně zapojovat kompenzační činitele po celý den výuky je velmi unavující.

- Snížená koncentrace, slabší pozornost, pomalejší pracovní tempo: je potřeba navýšit čas pro práci studenta až o $100 \%$ navíc, ze strany vyučujících je třeba dané zohlednit také při plnění úkolů v průběhu semestru, nejen při zkoušce.

- Specifika v rámci prostorové orientace a samostatného pohybu: potřeba „natrasovat“" si místa spojená se studiem, at’ již v exteriéru, či v interiéru budov výuky, knihovny, menzy, vysokoškolských kolejí. Naučit se potřebné trasy v rámci prostorové orientace a samostatného pohybu může každému studentovi trvat různě dlouho, záleží na tom, zda preferuje chůzi s vodicím psem či pouze s bílou holí, jakou má schopnost orientace v prostoru. Někomu může trvat naučit se potřebné trasy jeden týden či měsíc, s jiným studentem procházíme trasy celý semestr, než si je zautomatizuje. Někdo naopak preferuje vždy průvodcovskou službu.

- Nutnost úpravy podmínek výchovně-vzdělávacího procesu, limitovaná volba povolání a pracovního uplatnění: zde je velmi důležitá volba správného studijního oboru a později také pracovního uplatnění.

- Vliv na sociální kontakt, oblast partnerských vztahů, formování a udržování sociálních vztahů: důležité je fungování studenta v komunitě vysokoškolských studentů bez zrakového postižení, možnost navázat kontakt, udržet si vztahy. Míra zapojení do society spolužáků závisí také na temperamentu, není závislá jen na zrakovém postižení.

- Specifika v oblasti psychického života člověka: s touto oblastí se pojí nejen skutečnost, zda jedinec uspěje u zkoušky, prožitek úspěchu/neúspěchu, ale také schopnost studenta se zrakovým postižením čelit stresu a nárokům vysoké školy - koneckonců je to př́iprava na běžný život mimo vysokou školu.

b) Důsledky zrakového postižení a vysokoškolský student se slabozrakostí a zbytky zraku:

- Senzorický deficit, informační bariéra: student zpravidla funguje s optickými a jinými pomůckami, které umožňují nastudování potřebných textů, obrázků, schémat, učební látky celkově. Tato oblast 
se samozřejmě dotýká také schopnosti využít zbytků zraku a kompenzačních pomůcek pro vyřízení záležitostí spojených se studiem, např́iklad na studijním oddělení.

- Narušení vývoje poznávacích procesů, podobně jako u nevidomosti: využívání zraku za pomocí pomůcek při práci do blízka vyžaduje také dodržování zrakové hygieny.

- Snížená koncentrace, slabší pozornost, pomalejší pracovní tempo: je potřeba navýšit čas pro práci s textem studenta o 50-100\%.

- Ztížená prostorová orientace, samostatný pohyb a sebeobsluha: většina studentů této kategorie v úvodu studia využije nácvik tras (trasování), potřebuje si tedy projít nutné trasy v rámci studia (kolej-škola, škola-menza). V průběhu studia jsou však jedinci v přemist'ování mezi učebnami a budovami často samostatní, nebot' využívají k orientaci v menší či větší míře zbytky zraku. Nácvik tras zde tedy nemusí trvat tak dlouho jako u studenti̊ s nevidomostí, záleží na povaze zrakových obtíží.

- Důležitost úpravy podmínek výchovně-vzdělávacího procesu, limitovaná oblast volby povolání, pracovního uplatnění vzhledem ke zrakovému postižení: platí zde totéž, co bylo zmíněno výše.

- Vliv na sociální kontakt, oblast partnerských vztahů, formování a udržování sociálních vztahů: pokud není zrakové postižení viditelné, mohou si spolužáci myslet, že se jedná o jedince vidícího, zde je na místě osvěta, která může vyjít jak od samotného studenta se zrakovým postižením, tak od informovaného pedagoga.

- Větší sugestibilita, horší adaptabilita, možné pocity méněcennosti: nároky studia si vyžadují jak psychohygienu, tak hygienu zrakovou i jisté osobnostní předpoklady jedince. Pokud je potřeba podpory, je k dispozici školní psycholog.

c) Důsledky zrakového postižení a vysokoškolský student s poruchami binokulárního vidění:

- Narušení zrakového vnímání v rovině zrakové analýzy a syntézy, lokalizace a hloubkové, prostorové vidění, pomalejší utváření představ: jedinec nemusí být tak zdatný, pokud jde o přesnost, detailní práci, např́klad při rýsování či při zachycení vnímané reality na papír při kresbě.

- Pomalejší a méně přesné motorické reakce na zrakové podněty: pokud jde o míčové hry při tělesné výchově, může mít student s po- 
ruchami binokulárního vidění obtíže. Se zmíněným samozřejmě souvisí vhodnost studijního oboru, kterou by měl každý takový student zvážit.

- Unavitelnost, slzení a pálení očí: vyvstává zde důležitost zrakové hygieny.

- Pocity méněcennosti z důvodu nerovnocenného postavení očí: sociální aspekt a přijetí studenta s nerovnocenným postavením očí okolím hraje důležitou roli v jeho integraci do skupiny vrstevníků. Každý takový student se s touto skutečností vyrovná jinak, opět by měl být v prŕípadě potřeby $\mathrm{k}$ dispozici školní psycholog.

Jak může čtenář vidět, student se zrakovým postižením čelí každý den celé řadě výzev spojených s překonáváním překážek souvisejících se studiem. Přesto je třeba si uvědomit, že ačkoliv vyžaduje vyšší míru podpory než student bez postižení, může také žít spokojený život vysokoškoláka. A právě $\mathrm{k}$ některým konkrétním příkladům $\mathrm{z}$ praxe se ještě níže vrátíme. Nyní si přiblížíme to, jak bychom měli se studentem se zrakovým postižením komunikovat, necháme padnout mýty zvěčněné společností a upřesníme si, čemu se vyhnout a čeho se naopak bát nemusíme. Také studenti se zrakovým postižením jsou jen lidé, nejsou to osoby vyznačující se nálepkou pozor, nevidím.

\subsection{Jak nejlépe komunikovat se studentem se zrakovým postižením?}

Vývoj pojmu komunikace najdeme v latině, pochází z latinského slova communicare a znamená v překladu oznamovat, radit se s někým, svěřovat se, ale také jej lze chápat coby společné, pospolité, vlídné, laskavé, obecné (Leško, 2008). Komunikace se vytváří jako vztah mezi minimálně dvěma subjekty, jež o sobě vědí, společně subjektivně sdílejí, prožívají a zaujímají stanovisko k určité objektivní situaci. Záleží na tom, jak situaci zúčastněné osoby reflektují, jak ji řeší a jak na ni společně reagují. Jedná se o transakční proces, ve kterém může každý jedinec vystupovat současně jako mluvčí i jako posluchač (Pokorná, 2010). Bytešníková (2012) upozorňuje, že přijetí jediné výhradní definice komunikace je zcela nemožné. K základním komponentám charakteristickým pro primární tematické okruhy vymezení ko- 
munikace patří následující klíčová slova: symboly, slova, řeč, porozumění, interakce, vztah, sociální proces, přenos, směna, spojování, společenskost, prostředek, intencionalita, čas, situace, moc.

\subsubsection{Padlé mýty aneb komunikace se studentem s nevidomostí}

Na tomto místě se budeme zabývat komunikací v př́imo určeném kontextu. V rámci následující části textu si shrneme desatero komunikace se studentem se zrakovým postižením na vysoké škole. Budeme se soustředit na důležité body týkající se kontaktu se studentem se zrakovým postižením obecně i vzhledem ke konkrétním situacím (upraveno podle NRZP ČR, 2016):

a) Při kontaktu se studentem se zrakovým postižením je nutné jednat s ním tak, aby se necítil ponížen. Jednáme s osobou přirozeně a prímo, nikoliv přes jeho průvodce, asistenta, zapisovatele či jiného pracovníka, který jej doprovází.

b) Osoba (pedagog, nepedagogický pracovník) jednající s nevidomým studentem by měla pozdravit jako první. Pozdrav s vlastním představením je důležité spojit s oslovením typu: „Dobrý den, paní Bílá, jsem pan Nový," aby nevidomý věděl jistě, že pozdrav patř́ jemu.

c) Také při odchodu z místnosti je vhodné upozornit nevidomého studenta na to, že dotyčná osoba opouští místnost. Odběhne-li si např́íklad předčitatel z místnosti, kde probíhá předčítání, měl by tuto skutečnost oznámit nevidomému studentovi.

d) Podání ruky na pozdrav nahrazuje nevidomému studentovi vizuální kontakt. Při setkání postačí oznámit „podávám vám ruku“. Při rozhovoru je velmi důležitý rovněž oční kontakt s nevidomým. Není vůbec vhodné odvracet při rozhovoru tvár̆, protože to jedinec obvykle pozná.

e) Když bude pedagog vyžadovat aktivní účast studentů na nějaké aktivitě v rámci výuky cvičení/workshopu/semináře, je nezbytné nevidomému studentovi vysvětlit, co se bude dít, stručně popsat jak použité přístroje, tak vlastní činnost. Na řadu může přijít také př́mé vedení jedince, především u pohybové aktivity.

f) Dveře do místností by měly zůstávat bud' zcela otevřené, nebo zcela zavřené. 
g) Věci nevidomého studenta by měly zůstat na svém místě. S věcmi není vhodné manipulovat bez vědomí jedince, nemusel by je pak najít.

h) Při komunikaci s nevidomým studentem můžeme bez obav použít slova jako vidět, kouknout se, mrknout, prohlédnout si. I jedinci s nevidomostí tato slova používají k vyjádření způsobu vnímání: cítit, dotýkat se.

i) Pokud budeme nevidomého studenta doprovázet, nabídneme mu, aby se chytil naší paže (nejlépe v nadloktí), tak může jít bezpečně krok za námi a sledovat směr našich pohybů. Nikdy netlačíme nevidomého studenta před sebou! Stejně tak nechytáme za jeho ruku s bílou holí, je to pro něj stejné, jako kdyby nám někdo zakryl oči.

j) Při sjednání konzultace $\mathrm{k}$ výuce, zkoušce $\mathrm{v}$ př́ípadě vyučujícího nebo předčítání $\mathrm{v}$ případě studijní asistence by měl být nevidomý student objednán na určitou hodinu. Tu je vhodné dodržet, aby se předešlo nervozitě nevidomého studenta v neznámém prostředí. Je vstřícné nevidomému studentovi, který čeká před dveřmi kanceláře vyučujícího/pracovníka, sdělit, že o něm dotyčný ví.

Výše zmíněné tipy pro kontakt s nevidomým studentem ještě nejsou vyčerpávajícím výčtem. Pokud totiž jedinec vlastní vodicího psa, měli bychom rovněž vědět pár důležitých věcí, týkajících se kontaktu s nevidomým studentem, kterého vede vodicí pes. Vodicí pes totiž není ani mazlíček, ani hračka, on v průběhu dne, kdy doprovází nevidomého, pracuje. Pojd’me se tedy podívat na specifika jednání, která bychom měli znát (upraveno podle Dvořák, 2016):

a) Pokud má s sebou nevidomý student vodicího psa, pak psa nevyrušujme při jeho práci, tedy se nedožadujme jeho pozornosti mlaskáním, voláním, hvízdáním a jinak. Velmi mu tím ztěžujeme jeho soustředěnou práci.

b) Bez vědomí nevidomého majitele na vodicího psa nesaháme, nehladíme jej, i kdyby to bylo v dobrém úmyslu. Je slušností nejdř́ve oslovit nevidomého studenta a zeptat se, zda souhlasí, abychom si psa pohladili.

c) Vodicího psa k sobě nevoláme, nutkání ke komunikaci zaměříme na jeho majitele.

d) Psovi bez vědomí majitele nenabízíme jídlo ani pamlsky. Kondice a dobrý zdravotní stav jsou základem pro jeho práci a dlouhý život.

e) Chceme-li pomoci nevidomému studentovi, kterého vede vodicí pes, vždy jedince nejdříve oslovíme a zeptáme se, zda naši pomoc potřebuje. 
Neměli bychom se urazit, když ji odmítne, může být plně soustředěn na svou cestu.

f) Pomáháme-li nevidomému studentovi, nemanipulujeme se psem, komunikujeme s člověkem a slovně doprovázíme, co děláme (můžeme tedy popisovat).

g) Pokud budeme mimo univerzitu a půjdeme-li po ulici se svým vlastním psem, neměli bychom mu dovolit vodicího psa při práci obtěžovat, očichávat či jinak vyrušovat. Míjíme-li nevidomého člověka s vodicím psem, měli bychom mít svého psa vždy na vodítku. Podobně také pokud nastupujeme se svým psem do dopravního prostředku, dáme přednost člověku s vodicím psem. V dopravním prostředku umožníme umístění vodicího psa a uvolníme vhodné místo.

\subsubsection{Jak na chybné domněnky aneb efektivní komunikace s jedincem se slabozrakostí či zbytky zraku}

Ještě stále jsme nevyčerpali základní pravidla komunikace s jedinci se zrakovým postižením. Neměli bychom zapomínat také na skutečnost, že ne každý jedinec se zrakovým postižením je plně nevidomý a ne na každé takové osobě musí být zrakové postižení od pohledu hned zřetelné. Na tomto místě si ještě shrneme dvanáctero kontaktu se slabozrakým studentem (upraveno podle Tyfloservis, o. p. s., 2007):

a) Zraková vada může být někdy nápadná, jindy si jí nemusíme ani všimnout. Ne vždy platí, že čím více dioptrií student má, tím hưře vidí. Některým slabozrakým dioptrické brýle nepomáhají.

b) Může se stát, že se setkáme se studentem se slabozrakostí, který bude citlivější na silné osvětlení - mluvíme o světloplachosti. Takový student bude pravděpodobně preferovat nošení tmavých brýlí, použití méně intenzivního osvětlení v místnosti nebo zatemnění oken. $\mathrm{V}$ takovém př́padě nejsou sluneční brýle módním výstřelkem.

c) Jiným jedincům se slabozrakostí se výrazně zhorší vidění při nízké intenzitě osvětlení, což se řeší silnějším osvětlením - mluvíme o šerosleposti. At' již jsme pedagogové, pracovníci podporující slabozrakého studenta při studiu, nebo jeho spolužáci, bud'me pozornější, když slabozraký vychází na sluncem zalitou ulici nebo když vstupuje do špatně osvětleného domu či obchodu. 
d) Také přizpůsobení na změnu osvětlení může slabozrakým trvat velmi dlouho. Mohou se takzvaně rozkoukávat i hodinu tam, kde se zdravé oko adaptuje během několika vteřin.

e) Výjimečně se můžeme setkat s člověkem, který vůbec nerozlišuje barvy či vidí černobíle. Častá je porucha rozlišování jen některých barev. Nemusíme se bát upozornit slabozrakého na případné omyly.

f) Snížená zraková ostrost a omezení zorného pole způsobují slabozrakým studentům mnoho praktických obtíží. Člověk se zúženým zorným polem má sníženou schopnost orientace v prostoru, při svém pohybu používá bílou hůl. Někdy, při zachované zrakové ostrosti, může takový jedinec číst i běžný text. Při nízké zrakové ostrosti slabozrakých studentů bývají problémy se čtením, rozlišováním drobných předmětů a s poznáváním lidí.

g) V dobře známém prostoru se slabozraký student bude pohybovat zpravidla bez obtíží a bezpečně. V novém neznámém prostředí, např́ílad student nově nastoupený na univerzitu, může ale mít velké potíže při orientaci a potřebovat naši pomoc.

h) Student se slabozrakostí může v době přechodného zhoršení podmínek pro vidění užívat postupů a pomůcek typických pro nevidomé, jako jsou tmavé brýle, bílá hůl aj.

i) Pokud je potřeba, měli bychom umožnit slabozrakým přistoupit blíž k informačním tabulím a k prohlíženým předmětům. Ideální je, mohou-li si věci vzít do ruky. Počítejme s tím, že pro vnímání zrakem potřebují slabozrací studenti více času, používají totiž při tom různé pomůcky: speciální brýle, lupy, dalekohledová zařízení.

j) Pokud bude pedagog připravovat pro slabozrakého studenta nějaký text (studijní text či test), měl by dát přednost velkému tiskacímu písmu bez zbytečných okras před písmem psacím, na počítači volí písmo bezpatkové. Zvětšení písma je podle povahy zrakového postižení u každého jiné. Většinou si jedinec sám řekne, jakou velikost písma používá (nap̌r. font Arial, velikost 26).

k) Celkově bude jedinci se slabozrakostí vyhovovat kontrast: černý fix na bílém papíre, žlutá hrana na tmavém schodu, jasně čitelná by měla být i vyobrazení označující WC, sprchy atp.

1) A opět platí to, co bylo zmíněno u nevidomosti - neměli bychom čekat na to, až nás slabozrací požádají o pomoc, můžeme ji nabídnout sami. Pozdravíme raději jako první, přestože to nemusí odpovídat etiketě. 
Můžeme studentovi přečíst špatně čitelný text. Upozorníme včas na věci, kterých si nemusejí ani všimnout. Potíže slabozrakých studentů jsou do značné míry individuální, nemusíme se ostýchat se jich př́ímo zeptat, s čím bychom mohli pomoci.

\subsubsection{A další specifika komunikace se studentem na vysoké škole / univerzitě}

Kromě výše zmíněných specifik ve vztahu ke stupni zrakového postižení lze dále hovořit o přizpo̊sobení komunikace vzhledem ke studiu na vysoké škole či univerzitě. Tímto se dostáváme ke skutečnosti, že zde vystupuje hned několik okruhů, které mají k tématu vztah. Jednak sem patří obecně lidská komunikace, výše zmíněná doporučení pro komunikaci s jedincem se zrakovým postižením, lidský přístup a pravidla slušného chování. Druhou oblastí je písemná komunikace, knihy, studijní texty poskytované vyučujícím a jejich úprava do př́stupné podoby pro studenta se zrakovým postižením (digitalizovaný dokument, zvětšený černotisk, Braillovo písmo), možnost využití počítače se speciálním softwarem při výuce nebo služba studijní asistence. Poslední důležitou sférou je elektronická komunikace, ne/př́stupnost webových stránek, e-mail, technická podpora.

Dále se budeme zabývat podporou, která je studentům poskytována vysokou školou, službami, pomůckami, a zvlášt také službou digitalizace. 


\section{Podpora poskytovaná studentům se zrakovým postižením na vysokých školách a univerzitách}

Kromě současně platného školského zákona č. 561/2004 Sb., ve znění pozdějších předpisů, se $\mathrm{k}$ podpoře studentů se zrakovým postižením na vysoké škole vztahuje celá řada dalších předpisů.

Na základě evropského standardu se Česká republika zavázala, že zajistí rovnoprávné zapojení studentů se specifickými potřebami do vysokoškolského či univerzitního vzdělávání. Klíčové jsou též zákony vztahující se ke vzdělávání osob se zdravotním postižením, mezi nimi zákon č. 111/1998 Sb., o vysokých školách, ve znění pozdějších předpisů, jenž hovoří o rovnoprávném zapojení těchto osob do běžného života. Mezi dalšími důležitými dokumenty jsou: Listina základních práv a svobod, Úmluva o právech osob se zdravotním postižením, Národní plán podpory rovných příležitostí pro osoby se zdravotním postižením na období 2015-2020, Dlouhodobý záměr vzdělávání a rozvoje vzdělávací soustavy České republiky na období 2015-2020, Strategie vzdělávací politiky České republiky do roku 2020, která se stala základním kamenem české vzdělávací politiky, nebo Akční plán inkluzivního vzdělávání (2019-2020). S legislativními dokumenty se pojí rovněž financování zvýšených nákladů na studium studentům se zrakovým (či jiným) postižením. Do roku 2011 byly servisní a poradenské služby určené naší cílové skupině zpravidla hrazeny prostřednictvím rozvojových programů Ministerstva školství, mládeže a tělovýchovy ČR, jež získávaly jednotlivé vysoké školy. Od začátku roku 2012 došlo ke změně ve financování těchto služeb v podobě normativního financování zvýšených nákladů na studium studentům s rozličnými druhy a stupni zdravotního postižení (Horváthová, Pastieriková, 2017).

Ministerstvo školství, mládeže a tělovýchovy ČR (2019) stanovuje skrze metodický pokyn pravidla pro výpočet a poskytování dotace jednotlivým vysokým školám. Sledována je připravenost školy na poskytování jednotlivých služeb (institucionální a personální zabezpečení, existence vnitřních legislativních opatření). Nejen finance napomáhají ke zvyšování kvality poskytování podpůrných služeb studentům se zrakovým postižením na vysokých školách, nezanedbatelná je také existence zájmového sdruže- 
ní - Asociace poskytovatelů služeb studentům se specifickými potřebami (založena 2013, více na www.ap3sp.cz).

V první řadě je však studentovi nejblíže právě podpưrné pracoviště dané vysoké školy či univerzity. Nastavení a podoba podpory vychází z vnitřních norem a předpisů instituce i obecně legislativně uznávaných dokumentů.

\subsection{Student se zrakovým postižením v Centru podpory studentů se specifickými potřebami}

Centrum podpory studentů se specifickými potřebami (dále jen CPSSP nebo Centrum) je celouniverzitní zařízení poskytující komplexní odborný poradenský, technický a terapeutický servis studentům s postižením, kteří studují na některé z osmi fakult Univerzity Palackého v Olomouci. Centrum, původně pod názvem Centrum pomoci handicapovaným, vzniklo roku 1996 při Katedře speciální pedagogiky (současném Ústavu speciálněpedagogických studií PdF UPOL). V pozdějším období prošlo renovací a zkvalitněním služeb, především pak díky podpoře projektů, které byly realizovány na Pedagogické fakultě Univerzity Palackého, převážně na Ústavu speciálněpedagogických studií (Horváthová, Pastieriková, 2017).

Možnost stát se klientem Centra je zcela dobrovolná a závisí na osobním uvážení studenta se zrakovým postižením, zda po dobu studia bude využívat některou z nabízených variant podpory, či nikoliv. V případě navázání spolupráce jsou veškeré aktivity koordinovány prostřednictvím příslušného koordinátora služeb, který zajistí naplnění specifických potřeb konkrétního studenta a bude usilovat o zajištění rovných příležitostí a maximálního studijního komfortu s důrazem na individuální potřeby každého klienta. Servis, který CPSSP poskytuje (mimo sebeobsluhu a volnočasové aktivity), není zpoplatněn, je poskytován zdarma. Služby jsou určeny studentům se zrakovým postižením, kteří jsou pro účel jejich poskytování rozděleni do dvou kategorií:

a) A1: studenti, jejichž zraková vada umožňuje práci zrakem (a to i s textem), s běžnými formáty dokumentů, včetně vizuálních; klienti, u nichž úprava obrazu pozůstává ve zvětšování nebo jiných změnách optického charakteru. 
b) A2: studenti se zrakovým postižením, kteří pracují bud's hmatově tišsěnými dokumenty, nebo s odečítači obrazovky (v kombinaci s hmatovým displejem nebo hlasovým výstupem).

\subsubsection{Výčet služeb}

Servis, který je přímo určen studentům se zrakovým postižením, může zahrnovat následující výčet služeb (přičemž záleží na individuálních potřebách studenta):

a) Studijní asistence.

b) Osobní asistence.

c) Adaptace studijních materiálů.

d) Konzultační činnost.

e) Metodická podpora (např. pedagogům).

f) Zapůjčení kompenzačních pomůcek souvisejících se studiem.

Na tomto místě si přibližíme, co konkrétně výše uvedený výčet služeb zahrnuje. Do služeb studijní asistence patří průvodcovské služby související se studiem, nácvik prostorové orientace a samostatného pohybu a předčitatelské služby. Dále mohou být poskytovány služby osobní asistence v př́ípadě vícenásobného postižení, například kombinace zrakového a tělesného postižení. Třetí oblastí služeb je adaptace studijních materiálů, která zahrnuje digitalizaci textů, jejich převod do elektronické podoby, převod černotisku do Braillova písma, přepis zvukových záznamů přednášek a seminářů, zvětšování textů, modifikace studijních materiálů do reliéfní podoby, tvorbu reliéfní grafiky.

Mimo zmíněné je nabízena konzultační činnost, respektive konzultace k přijímacím zkouškám, poradenství při výběru studijního oboru, konzultace pro pedagogy a ostatní pracovníky UP v Olomouci, pro rodinu uchazeče o studium na UP, řešení aktuálních problémových studijních záležitostí. V neposlední řadě může být poskytována metodická podpora, která je obvykle směřována pedagogům (pomoc při zpracování individuálních studijních plánů, pomoc při zpracování adaptovaných studijních textů a koncepce výuky). 
Neméně důležité je materiální a technické zabezpečení, možnost zapůjčení kompenzačních pomůcek optického, akustického i taktilního charakteru včetně pomůcek na bázi počítačů - počítač s hlasovým výstupem či zvětšovacím softwarem, různé druhy lup, Pichtův psací stroj, bílá hůl aj. (http://cps.upol.cz [online] [cit. 12. 2. 2019]).

\subsubsection{Př́ijemci a oblasti podpory}

Podpora však nemusí být směřována jen ke studentovi se zrakovým postižením, ale $\mathrm{v}$ obecném měřítku je směřována $\mathrm{k}$ uchazečům o studium, studentům denního i dálkového studia a účastníkům programů celoživotního vzdělávání se zrakovým postižením na všech fakultách UP; pedagogickým i nepedagogickým pracovníkům UPOL, kteří se setkávají se studentem se zrakovým postižením; učitelům a poradenským pracovníkům na středních školách se zájmem o možnosti vzdělávání studentů se specifickými potřebami; intaktním studentům, kteří mohou využít služby centra v oblasti poradenství i proškolení $\mathrm{v}$ př́istupech k osobám se zrakovým postižením. Navíc se studenti se zrakovým postižením vyznačují heterogenitou, která s sebou nese různou míru podpory, jež se odvíjí od povahy obtíží, které bychom mohli shrnout do následujících oblastí:

a) Sebeobsluha a mobilita: schopnost zajistit si potřeby běžného každodenního života; samostatný přesun z místa na místo; schopnost orientovat se $\mathrm{v}$ prostředí prostřednictvím informačních tabulí, schopnost získávat a zpracovávat informace $\mathrm{v}$ rámci nového prostředí, využívání vizuálních informací ve výuce.

b) Sociální a komunikační zručnost: komunikační a informační bariéra, pozitivní sebeprezentace, prezentace vlastního postižení a způsob zvládání jeho důsledků; umění požádat o pomoc či naopak schopnost pomoc odmítnout; umění vysvětlit, $v$ čem a jakým zpo̊sobem je potřeba pomoci; prezentace a obhájení vlastního názoru; navazování a udržování kontaktů, vlastní iniciativa $\mathrm{v}$ překonávání předsudků a bariér.

c) Akademická zručnost: vhodné techniky učení, disciplinovaný vztah ke studiu; využívání konzultací; produkování písemných prací (referáty, seminární/závěrečné/zápočtové práce); systém zaznamenávání přednášek; čtení s porozuměním a s tím související přiměřená úroveň psaného textu. 
d) Technická zručnost: schopnost využívat pomůcky usnadňující běžný život, sebeobsluhu a orientaci (ovladač VPN 01, bílá hůl, Colortest aj.); technické zajištění práce s informacemi (diktafony, zápisníky, notebooky, braillské řádky, počítače s hlasovým výstupem atd.); odpovídající technická zručnost vhodná dle charakteru univerzitního vzdělávání (upraveno dle Horváthová, Pastieriková, 2017).

\subsection{Knihovna pro uživatele se specifickými nároky}

Také Univerzita Palackého v Olomouci zajištuje přístupnost studijních materiálů studentům se zrakovým postižením. Katalog literatury pro užiatele se specifickými nároky zajištuje dostupnost studijních materiálů v adekvátních formátech, jež umožňují studentům se zrakovým postižením (či jiným typem postižení) efektivně pracovat s knihami a studijními texty. Formálně je knihovna vedena jako takzvaně specifická a je součástí systému Knihoven Univerzity Palackého v Olomouci. Knihovna se řídí knihovním rádem Univerzity Palackého v Olomouci i metodickými pokyny platnými pro ostatní knihovny univerzity, knihovní fond je katalogizován v Souborném katalogu UP (https://www.knihovna.upol.cz/katalogy [online] [cit. 12. 2. 2019]).

Pokud student se zrakovým postižením hledá určitou knihu (př́padně jeho pedagog, studijní asistent), je možné vyhledávat současně nejen knihy v katalogu literatury pro uživatele se specifickými nároky Univerzity Palackého, ale hned v několika katalozích najednou. Středisko Teiresiás Masarykovy univerzity vytvořilo $\mathrm{v}$ rámci projektové podpory celostátní knihovnu př́stupných dokumentů - Daleth (více na https://www.teiresias.muni.cz/ daleth/). Dle zadaných parametrů je možné vyhledávat knihy a studijní materiály v rámci katalogů knihoven po celé České republice. Mezi přidanými knihovnami jsou v rámci souborného katalogu následující instituce:

a) Středisko Teiresiás, Masarykova univerzita, Brno.

b) Středisko Elsa, ČVUT v Praze.

c) Carolina - středisko digitalizace studijních zdrojů Informačního, poradenského a sociálního centra, UK v Praze.

d) Knihovna pro studenty se speciálními potřebami, Pedagogická fakulta, UK v Praze.

e) Středisko Augustin, Univerzita Hradec Králové. 
f) Digitální knihovna - Dokumenty pro studenty se specifickými potřebami, VUT v Brně.

g) Centrum podpory studentů se specifickými potřebami, Univerzita Palackého v Olomouci.

h) Centrum podpory studentů se specifickými potřebami, Jihočeská univerzita v Českých Budějovicích.

i) Knihovna digitálních dokumentů (KDD), SONS ČR.

j) Knihovna a tiskárna pro nevidomé K. E. Macana, Praha.

k) Souborný katalog Masarykovy univerzity, Brno.

1) Centrální katalog Univerzity Karlovy v Praze.

m) Knihovna JABOK, Vyšší odborná škola sociálně pedagogická a teologická, Praha.

n) Národní knihovní služba Knihovny Kongresu USA pro nevidomé a zdravotně postižené (https://www.teiresias.muni.cz/daleth/ [online] [cit. 28. 2. 2019]).

Po zatržení všech dostupných položek zastupujících jednotlivé knihovny vyhledávač vygeneruje hledanou knihu všude tam, kde je dostupná. Důležitou informací je pak také to, zda je hledaná kniha v tištěné černotiskové podobě, elektronicky či formou audionahrávky. Uživatel se tak díky tomu dostane k potřebné knize odkazem na konkrétní knihovnu, v rámci níž je text dostupný.

Dané usnadňuje nejen hledání studentům se zrakovým postižením, ale také pracovníkům našeho centra. Pokud pracovník pro digitalizaci zjistí, že je kniha v České republice v elektronické podobě hotova, nemá cenu na ní pracovat znovu. Student se zrakovým postižením si pak může daný text od dotyčné knihovny vyžádat. Pokud existují knihy, které dosud nikdo nezpracoval, pak jsou právě tyto v rámci služby digitalizace studijních textů zpracovávány.

A v čem je vlastně knihovna pro studenty se zrakovým postižením jiná? Specifičnost knihovny spočívá právě v typologickém složení knihovního fondu, ve formátu knihovních jednotek a v akvizičních metodách - digitalizace, braillský tisk. Na Univerzitě Palackého má správu specifické knihovny na starosti Centrum podpory studentů se specifickými potřebami UPOL ve spolupráci s Knihovnou Univerzity Palackého v Olomouci (http://cps. upol.cz [online] [cit. 12.2. 2019]). 
Teiresiás (https://www.teiresias.muni.cz [online] [cit. 29. 3. 2019]) dodává, že každá taková specifická knihovna může pomoci se zajištěním dostupnosti studijních materiálů nejen studentům se zrakovým postižením, ale též osobám s jinými typy postižení. Jedná se např́ílad o čtenáře s postižením jemné motoriky rukou, s kombinací zrakového a tělesného postižení apod. Spadají sem uživatelé, kteří mohou mít objektivní fyzické obtíže při práci s běžnými knihovními dokumenty (https://www.teiresias.muni.cz/ cz/knihovna-a-vydavatelstvi [online] [cit. 28. 2. 2019]).

\subsection{Každá služba něčím začíná...}

Podpora určená studentům se zrakovým postižením má v rámci univerzity svůj začátek a přesně daný postup. První setkání může proběhnout již během dne otevřených dveří, případně na základě individuální konzultace. Obvykle však začíná právě podáním přihlášky ke studiu a zatržením kolonky - zrakové postižení. V takovém případě je student kontaktován koordinátorem služeb s dotazem potřeby úpravy podmínek přijímací zkoušky. Koordinátor zjištuje typ a stupeň zrakového postižení a důsledky z něj vyplývajících. Na základě komunikace je vytvořen požadavek úpravy podmínek přijímacího řízení.

U studentů, kteří jsou slabozrací či využívají zbytky zraku, se může jednat o úpravu písma testu v tištěné či elektronické podobě. Obvykle je volen bezpatkový font písma (např́klad Arial, Calibri) od velikosti 14 výše. Uchazeči o studium s nevidomostí mohou žádat test $\mathrm{v}$ tištěném Braillově písmu. At již uchazeči nevidomí, tak slabozrací či se zbytky zraku mohou konat zkoušku za prrítomnosti předčitatele a zapisovatele nebo s úpravou testu do elektronické podoby pro odečítač obrazovky (zvětšení obrazovky nebo audiopodoba předčítaná softwarem do sluchátek, často s přidáním braillské klávesnice).

Kromě samotné úpravy testu mohou uchazeči žádat také průvodcovskou službu na místo konání přijímací zkoušky. Ve chvíli, kdy se uchazeč o studium stává studentem se zrakovým postižením, je kontaktován podruhé s dotazem, zda využije služeb podpưrného centra. V případě kladné odpovědi je sjednána osobní schůzka koordinátora se studentem. Co je obsahem setkání? 
V případě, že student vyžadoval úpravu podmínek přijímací zkoušky, pak má koordinátor o studentovi základní informaci týkající se zrakového postižení, preference práce s textem, informace ohledně pomůcek a technické podpory. Přesto je na místě zaměřit se na další informace včetně zjištění studijních potřeb jedince obecně. Koordinátor využívá pozorování, rozhovor, polostrukturovaný dotazník, případně analýzu dokumentů. Na základě zmíněného společně s klientem pojmenovávají studijní potřeby, míru a podobu podpory. V souvislosti s výše zmíněnými diagnostickými nástroji a podpůrnými doporučeními pracovník provádí takzvanou funkční diagnostiku. Výsledkem diagnostického procesu je sepsaná zpráva ze speciálněpedagogického vyšetření, kterou pracovník zakládá v centru a dává $\mathrm{k}$ dispozici studentovi. Ten může zprávu využít např́íklad pro vyučujícího k prokázání specifických studijních potřeb. Součástí služby by mělo být rovněž sepsání smlouvy o poskytovaném servisu. Student je seznámen s pravidly a fungováním centra, je poučen o jejich dodržování.

Koordinátora služeb zajímá hned několik následujících skutečností, které mohou souviset s poskytovanými službami:

a) Stav zraku, typ, stupeň postižení, způsob zrakové práce do blízka a do dálky.

b) Zdravotní stav studenta se zrakovým postižením, zda má ještě jiné zdravotní komplikace, zda bere léky.

c) Nastavení podpory v rámci předchozího vzdělávání na střední škole, využívané služby v průběhu předchozího vzdělávání.

d) Využívání služeb u dalších institucí věnujících se osobám se zrakovým postižením.

e) Využívané pomůcky (lupy, počítač se speciálním softwarem, bílá hůl, vodicí pes aj.).

f) Preference podpůrných služeb v rámci CPSSP UPOL.

Dále kromě uvedených položek dotazování mohou být pro nastavení podpůrných služeb v rámci centra využity následující nástroje, pomůcky, prostředky:

a) Orientační diagnostika hmatu skrze taktilní obrázky, mapy, plány či tištěné Braillovo písmo, braillský řádek připojený k počítači.

b) Vzorkovník písma pro slabozraké uživatele či studenty se zbytky zraku.

c) Pomůcky a obecné zhodnocení fungování s pomůckami (počítač se speciálním softwarem, televizní kamerová lupa, bílá hůl, diktafon aj.). 
Koordinátor by si měl utvořit co nejkomplexnější obraz o jedinci, jeho zrakovém postižení a studijních potřebách. Je logické, že proces speciálněpedagogické diagnostiky není jednorázovou záležitostí. Vždyt’ jen stupeň zrakového postižení se může během života jedince měnit, a stejně tak důsledky s tím spojené pro život i studium.

Pokud např́ílad student prvního ročníku nastupuje se zrakem v rovině zbytků zraku, nemusí to znamenat, že absolvuje vysokou školu se stejným stupněm zrakového postižení. Student pro studium potřebuje např́klad zvětšení textů na bezpatkové písmo fontu Arial, velikosti 32, v prvním roce studia. Ale ve třetím ročníku se již kvůli progresi vady může nacházet v rovině praktické nevidomosti, čímž se mění rovněž jeho potřeby a nastavení služeb. Např́iklad střídavě využívá zvětšení textu a střídavě počítač s odečítačem obrazovky (audiopodoba) nebo přechází primárně ke zvukové podobě studijních materiálů. Může se zvýšit potřeba průvodcovské služby, předčitatelský servis aj. Vždy samozřejmě záleží na průvodním očním onemocnění, zda je zde tendence k progresi zrakové vady či nikoliv, na dodržování zásad zrakové hygieny v případě využívání zbytků zraku atp.

\subsection{Obvyklý průběh a čerpání služeb}

Na začátku každého nového semestru je úkolem koordinátora zjistit u každého jednotlivého klienta se zrakovým postižením zapsaný rozvrh, jména, tituly a kontakty na jednotlivé vyučující. Ve fázi, kdy má pracovník tyto informace, kontaktuje jednotlivé vyučující každého studenta se zrakovým postižením zařazeného v evidenci služeb. Podle studentů vedených v evidenci služeb tak pracovník na začátku semestru pošle několik stovek e-mailů dotyčným vyučujícím. Mnozí se ozývají elektronicky či telefonicky zpět a konzultují úpravu podmínek jejich výukového předmětu pro studenta.

Začátek semestru s sebou nese rovněž domluvu a nastavení služeb pro konkrétního studenta. Nově nastoupivší studenti často vyžadují zajištění nácviku tras spojených se studiem a také intenzivnější pokrytí služeb asistenčních. Doba adaptace je u každého uživatele jiná. Například student s nevidomostí, který funguje s vodicím psem, se může učit nové trasy v průběhu zimního semestru a v letním semestru již může fungovat v rámci 
přemistování mezi známými místy výuky samostatně. Někteří studenti však mohou průvodcovskou službu preferovat po celou dobu studia. Nastavení služeb se tedy liší nejen po nástupu ke studiu a v jeho průběhu, ale též student od studenta.

Z nabídky výše uvedených služeb si student vybírá ty, které vyhovují jeho studijním potřebám (samozřejmě také s ohledem na doporučení vycházející z funkční diagnostiky). Aktivně se podílí na utváření služeb. Nevedeme studenty $\mathrm{k}$ tomu, aby byli pasivními př́jemci péče, ale aby byli aktivními činiteli služeb i svého života. Domníváme se, že právě toto je jeden z největších benefitů, který si mohou odnést do života po opuštění vysoké školy. Znamená to tedy v praxi např́klad to, že ve chvíli, kdy si student vyžádá studijní asistenci pro přednášku, koordinátor kontaktuje asistenty s požadavkem. Když se ozve volný asistent, poslední fází je předání kontaktů. Studentovi žádajícímu o službu i dotyčnému asistentovi je poslán společný e-mail s podrobnostmi dojednané spolupráce, časem, místem konání služby, a především se vzájemným kontaktem. Student se zrakovým postižením se pak na podrobnostech dále domlouvá sám s dotyčným asistentem. Jednak tím dostává zodpovědnost za své studium a zároveň se tímto způsobem předchází ztrátě informací v trojici koordinátor-student-asistent. Pokud dojde $\mathrm{k}$ neočekávané změně, například $\mathrm{v}$ čase služby, $\mathrm{z}$ důvodu nemoci apod., je tak možné na ni dostatečně rychle reagovat.

Důležitým obdobím studia pro každého studenta je zápočtový týden a zkouškové období včetně konání státních závěrečných zkoušek či praxí. Právě $\mathrm{v}$ době těchto mezníků může být čerpání služeb také předpokladem úspěšného absolvování studia.

Např́klad pro výkon praxí nevidomý student zvolí službu průvodce, předčitatele pro celou dobu konání praxe. Pokud je tedy splnění praxe naplánováno na 40 hodin, dobu dvou týdnů, což činí 4 hodiny denně, je studentovi $\mathrm{k}$ dispozici služba studijní asistence po dobu těchto 40 hodin plus př́ípadný čas navíc $\mathrm{v}$ rámci přesunů $\mathrm{z}$ koleje na místo praxe. Pokud si student přeje být maximálně samostatný a nevyžaduje předčítání, je možné s ním trasu na místo výkonu praxe natrénovat.

Co se týká výkonu zkoušek v rámci jednotlivých předmětů, vždy záleží na volbě studenta se zrakovým postižením. Někteří uživatelé služeb pre- 
ferují zkoušku ryze ústní, kdy nevyžadují službu studijní asistence. Na základě informování vyučujících koordinátorem na začátku semestru se dále s pedagogy sami či za pomoci koordinátora domluví na ústním plnění zkoušek místo testů. Jiní klienti pak podle předmětu a domluvy s vyučujícím žádají službu předčitatele, zapisovatele, případně vypůjčení počítače s odečítačem obrazovky či braillským řádkem pro konání testu v elektronické podobě. Podobně může Centrum zvětšit test běžné velikosti písma na požadovanou velikost na základě žádosti vyučujícího a studenta s předstihem před konanou zkouškou. Koordinátor může informování vyučujících na začátku semestru i aktivní domluvu samotného studenta s vyučujícím doplnit dalším konzultováním s pedagogem, vystavením potvrzení k úpravě zkoušky, řešením aktuálně vzniklé situace.

Podobný proces probíhá rovněž před konáním státních závěrečných zkoušek. Centrum může pro samotné konání státní závěrečné zkoušky zapůjčit potřebné pomůcky (počítač s odečítačem, braillský řádek) nebo zajistit studijní asistenci (průvodce, předčitatel, zapisovatel). Student se zrakovým postižením s předstihem nahlásí koordinátorovi datum, čas a místo konání státní závěrečné zkoušky včetně jména a příjmení předsedy státnicové komise. Koordinátor vytvoří potvrzení s doporučením k úpravě podmínek státní závěrečné zkoušky. Potvrzení zasílá předsedovi komise, aby byla komise informována o př́tomnosti studenta na zkoušce i o př́ípadných úpravách, které by měly být respektovány (od techniky až po navýšení času na prrípravu až o $100 \%$, př́tomnost asistenta).

Od začátku studia až po jeho ukončení tedy Centrum doprovází studenta na jeho studijní cestě jen za předpokladu, že si student služby čerpat přeje.

\subsection{Př́lklady $z$ praxe}

Příběhů z praxe koordinátora, asistentů a dalších pracovníků centra bychom mohli nastřádat mnoho. Na tomto místě si uvedeme některé $\mathrm{z}$ nich, které se týkají čerpání služeb, nastavení míry podpory nebo řešených situací. 


\subsubsection{Vzorový test a plnění zkoušky}

Uchazeč o studium H. si vyžádal vzorový test studijních předpokladů v Braillově písmu. Test jsme studentovi přpravili a poslali slepeckou zásilkou zdarma domü. Domluva služby proběhla v průběhu dne otevřených dveří, kam nás student přišel navštívit. Zároveň jsme společně prokonzultovali možnosti studia, služby a úpravu prijímacího řízení.

Přepis do Braillova písma je jen jedním z možných řěsení, studentce L. většina vyučujících na katedře pravidelně umožňuje plnění zkoušky ústně namísto digitalizace testu či jeho přepisu do Braillova písma. Vzhledem $k$ plné nevidomosti je tato alternativa plnění nejvhodnější možností pro obě strany.

\subsubsection{Změna oboru a akceptace postižení}

Student R. si vyžádal konzultaci ke změně oboru z di̊vodu plné ztráty zraku. Po úspěšném splnění prijímacího řízení, jemuž předcházela velmi náročná př́prava (nově navíc bez zraku), byl ke studiu prijat. Již před nástupem ke studiu proběhlo několik setkání se studentem i jeho rodičem. Komunikace pokračovala také po nástupu ke studiu, byl tedy zařazen do evidence CPSSP UPOL. V průběhu studia se však začaly objevovat četné komplikace $z$ dìvodu zvýšených nároků, které s sebou nese ztráta zraku obecnè. Ztráta zraku a psychická náročnost této situace vedla u studenta $k$ depresím a jiným psychickým obtižím. Vyrovnání se s postižením studenta proživá také rodina, což se promítá do celkového procesu adaptace i do komunikace s klientem. $\mathrm{Na}$ studenta jsou kladeny studijní nároky, navíc je potřeba, aby se naučil využivat ostatní smysly namísto zraku. S tímto se pojí trénink hmatu, výuka Braillova písma, nácvik chůze s bílou holí, využívání pomucek. Jedinec se musí naučit fungovat jako osoba se zrakovým postižením a provádět činnosti bez kontroly zraku. Nároky studia a proces vyrovnávání se s postižením byly tak náročné, že má student momentálně přerušené studium.

\subsubsection{Nácvik tras a další služby}

Studentka F. si hned po nástupu do studia vyžádala nácvik tras v rámci budovy fakulty a mezi budovami studia (kolej, menza, fakulta). Nácvik tras 
proběhl v pri̊běhu prvního týdne výuky. Po dvou týdnech „trasováni“ jsme se se studentkou domluvili na pravidelném využivání služby studijní asistence př́mo při výuce, a to predevším v podobě předčitatelské služby. Prưvodcovskou službu si studentka preje využivat spíše výjimečně, jelikož má většinu tras již nacvičených a orientuje se velmi dobře. Můžeme si všimnout, že na nácvik nepotřebovala mnoho času, studentka má velmi dobré orientační schopnosti i pamèt pro nové trasy. Jen v rámci konání praxe si studentka obvykle službu studijní asistence předem s centrem domluví, nebot' jde zpravidla o nové prostředí, kde se orientuje hưre.

Prostorové orientace se týká také další prípad: studentka O. studuje kombinovanou formu studia. První semestr studia si pro každý pátek výuky vyžádala službu prưvodce, který ji vyzvedl na nádraží, dovedl na místo výuky a opèt pak odpoledne prevedl zpět. V této době si navíc studentka pořizovala vodicího psa. Dalši semestr po několikátém trasování s vodicím psem a asistentem z centra začala studentka docházet na výuku sama. Zorientovala se jak $v$ rámci budovy fakulty, tak při prechodech $z$ nádraží na místo výuky a zpět. $V$ př́padě nových tras pro účel studia je Centrum studentce $k$ dispozici.

\subsubsection{Nevhodná volba oboru}

Student J. si vybral studijní obor Chemie i pres zrakové postižení v rovině slabozrakosti. Na dni otevřených dveří mu byly nabídnuty vhodnější alternativy vzhledem $k$ povaze postižení, avšak po úspěšném přijetí ke studiu se student presto rozhodl začít obor studovat. Student byl zařazen do evidence klientů se zrakovým postižením. Vyučující byli informováni o př́tomnosti studenta a v prípadě potřeby studijního asistenta ve výuce. Obtiže nastaly ve chvíli, kdy měl student v rámci predmètů laboratorního charakteru plnit pokusy, manipulovat s chemikáliemi, zkumavkami apod. Vyučující dovolil př́tomnost asistenta $v$ rámci laboratorních cvičení. Student však $v$ rámci cvičení nebyl schopen vykonávat řadu činností, a to hlavně kvưli potřebě prohlédnout si pokus z bezprostřední blizkosti několika málo centimetrü u objektu, nejlépe ještě s optickou pomůckou. V rámci většiny pokusư taková zraková práce nebyla možná $z$ dìvodu bezpečnosti práce. Přitomnost asistenta bohužel neřešila otázku provedení pokusů. Jaký smysl má v takovém prípadě podpora studijního asistenta, který odečítá studentovi probíhající dèj, 
popisuje, co lze sledovat, když samotný student nemůže pokus beze zbytku provést samostatně? Jak student zjistil sám dle své zkušenosti, obor si nezvolil vhodně, a proto se rozhodl jej změnit. Kdyby student dal na radu pracovníka centra $v$ den otevřených dveří, mohl se vyhnout semestru stráveném na nesprávném oboru.

\subsection{Návaznost na další instituce a spolupráce vysokoškolských středisek/center}

Spolupráce vysokoškolských center/středisek s dalšími institucemi či s ostatními odborníky by měla být rovněž součástí uceleného př́istupu pracoviště. Jedná se nejen o konzultování s kolegy a vedením v rámci centra, ale např́klad též o spolupráci s psychologem nebo jiným odborníkem, který může být pro Centrum nasmlouván ve prospěch intervence klientů.

$\mathrm{V}$ prrípadě potřeby je vhodná spolupráce $\mathrm{s}$ organizacemi tyflopedického charakteru - Tyfloservis, o. p. s., TyfloCentrum, o. p. s., SONS a další organizace, většinou z neziskového sektoru. $V$ případě, že vysokoškolské centrum neposkytuje službu, kterou student požaduje, může klientovi pomoci najít návaznost na instituci, jež daný servis zajistí. V praxi koordinátor může nejen doporučit jiné pracovišsě a předat kontakt studentovi, ale rovněž organizaci kontaktovat a kolegům sdělit, že se na ně uživatel centra obrátí.

Neméně důležité je propojení vysokoškolských center v rámci České republiky skrze Asociaci poskytovatelů služeb studentům se specifickými potřebami na vysokých školách (AP3SP) se sídlem v Brně. Jedná se o zájmové sdružení právnických osob poskytujících praktický servis studentům se specifickými potřebami na českých vysokých školách i ostatním členům české akademické obce, které bylo založeno roku 2013. Obsahem činnosti AP3SP je: rozvoj a zvyšování kvality profesionálních služeb poskytovaných studentům se specifickými potřebami na vysokých školách; ostatním členům akademické obce se specifickými potřebami; dbát na dodržování standardu kvality poskytovaných služeb cílové skupině; podporovat koncept rovného přístupu ke vzdělávání. Činnými orgány asociace jsou: rada asociace; členové asociace (plénum); vysokoškolská servisní centra. V rám- 
ci AP3SP dále působí jednotlivé pracovní skupiny, některé jsou stále činné, jiné po splnění cíle ukončily svou činnost, více viz aktuální informace na webu organizace (http://www.ap3sp.cz [online] [cit. 5. 4. 2019]).

\subsection{Koordinátor služeb a předpoklady pro výkon profese}

Koordinátor služeb pro studenty se zrakovým postižením by měl být vystudovaný speciální pedagog se zaměřením na tyflopedii (oftalmopedii), ideálně též speciální pedagog - andragog, připravený pro práci s dospělým klientem se zrakovým postižením starším 18 let. Měl by být schopen nižšího managementu v rámci organizace práce studijních asistentů a kolegů pro koordinaci digitalizace, který s tyflopedickým pracovištěm úzce spolupracuje, případně dalších zapojených pracovníků, jsou-li potřeba pro řešení požadavku uživatele služeb. Koordinátor se tedy pohybuje v mezích pomáhající profese a nižšího managementu, proto by měl disponovat kvalitami obou oblastí.

Bez řízení nelze produktivně pracovat a fungovat, jinak vzniká chaos. Dle situace a potřeb pracovníka lze využít různé styly řízení, situační řízení, od autoritativního, direktivního až po participační zaměřené na cíl, participační zaměřené na pracovníka či volně se zaměřením na spolupracovníka. S tímto pak souvisí způsoby chování, jednání, řízení, které jsou úspěšné více, méně, a ty, které jsou neúspěšné. Dané platí rovněž ve vztahu k náplni práce koordinátora. Podle klasického pojetí můžeme hovořit o třech stylech ř́izení:

a) Autokratický koordinátor služeb: je dominantní, hodně kontroluje, podřízení jsou nesamostatní a spíše pasivní, vztahy pak mohou být napjaté, a ačkoliv se jde na kvantitu výkonu, ne vždy je výsledek kvalitní.

b) Demokratický koordinátor služeb: podporuje aktivitu zaměstnanců, působí př́íkladem, prríkazy jsou méně časté než u předchozího typu, většinou jsou pak výsledky průměrné, ale dlouhodobě kvalitnější, atmosféra práce přátelská.

c) Liberalistický koordinátor služeb: spíše nezasahuje, je pasivní, pracovníci jsou samostatní, zainteresovaní, kvalita práce však může být kvưli chybějícímu vedení nízká i při vysoké zainteresovanosti, a vztahy pak napjaté nebo chaotické (upraveno dle Duchoně, Šafránkové, 2008). 
Z daného vyplývá, že demokratický typ vedení je do jisté míry z dlouhodobého hlediska nejvhodnější. Ne vždy však může být koordinátor schopen tohoto př́stupu dosáhnout, pokud je jeho povaha vyhraněně autoritativní nebo naopak liberalistická. Vždy se však dá na osobnostním ladění pracovat a učit se novým strategiím, způsobu jednání a chování. Mưže pomoci nejen další vzdělávání, ale také zkušenosti a léta praxe.

V 60. letech 20. století byl propagován situační přístup, kdy se pracovník přizpůsobuje řešené situaci, a může tak procházet mezi všemi výše uvedenými způsoby jednání. V rámci situačního přístupu pak můžeme mluvit dle řešení situace o kritériu, kdy vedoucí může přikazovat, koučovat, podporovat, delegovat. Rízení a motivace pracovníků se pak samozřejmě odvíjí od obsahu práce, a tak vedoucí dle potřeby např́iklad zvyšuje význam pracovního úkolu, posiluje zpětnou vazbu, stanoví krátkodobé cíle, zvyšuje pestrost práce apod. (Duchoň, Šafránková, 2008).

Koordinátor služeb tak má nelehký úkol přizpůsobit způsob řízení povaze pracovního úkolu studijní asistence, kvalitám i osobnostním charakteristikám asistenta (zaměstnance), a požadavku klienta. Vedení vyžaduje delegovat správně úkol $\mathrm{k}$ asistentovi. Tento úkol je pak spojen s př́mou prací se studenty se zrakovým postižením (průvodcovství, zapisování, digitalizace). Koordinátor by měl být rovněž schopen podporovat pracovníky, pokud přijdou s potřebou řešit problémovou situaci v rámci poskytování služby (např́klad nevhodné chování klienta). Zároveň by měl být schopen do jisté míry koučovat, tedy věnovat se $\mathrm{v}$ případě potřeby řešení interpersonálních problémů, věnovat se lidem, vztahům. Pokud je poté nezbytně nutné dokončit úkol, na němž např́klad koordinátor pro digitalizaci pracuje př́liš dlouho, je potřeba umět vhodným způsobem nařídit splnění úkolu.

Vedle nižšího managementu je koordinátor rovněž pracovníkem v rámci pomáhající profese, takže by měl mít osobnostní předpoklady pro její výkon. Na tomto místě si některé $\mathrm{z}$ nich budeme jmenovat (upraveno dle Michalíka, 2011):

a) Speciální či specializované vzdělávání: pracovník by měl mít příslušné vzdělání, jak bylo řečeno výše.

b) Zaměření na individuální potřeby jednotlivce: koordinátor služeb by měl brát ohled na individuální rozdíly mezi studenty se zrakovým postižením a dle toho pro daného klienta služby směřovat. 
c) Role praxe a dalšího vzdělávání: nestačí absolvovat obor, ale velmi podstatná je praxe a ochota se dále vzdělávat.

d) Speciální požadavky na strukturu osobnosti pracovníka: koordinátor by měl být spíše extrovert, př́padně ve středu mezi introverzí a extroverzí, osobnostně by měl být vyrovnaný se schopností zvládat stres v obdobích zvýšených požadavků ze strany klientů a vedení.

e) Vyšší riziko syndromu vyhoření: dané souvisí s osobností, temperamentem, ale také s léty praxe, spokojeností se zaměstnáním, osobním životem pracovníka, který by měl být schopen oddělit práci a volný čas. Chránit si svůj osobní život a volný čas, dbát na zdravý životní styl a odpočinek je podstatnou součástí prevence syndromu vyhoření.

f) Využívání etických norem: koordinátor služeb by měl dbát na ochranu osobních údajů a informací, v mezích slušného chování a etiky jednat jak s klienty, tak s kolegy a nadřízeným.

g) Specifické komunikační schopnosti: schopnost být empatický, naslouchat, použít parafrázování klientova sdělení, shrnout, na čem jsme se domluvili v rámci plánu služeb, to vše jsou kvality, kterými by měl pracovník v dané pozici disponovat. Soulad verbální a neverbální komunikace zde platí taktéž.

Uvedené vlastnosti, specifika a schopnosti jsou ukázkou toho, čím by měl koordinátor služeb pro studenty se zrakovým postižením disponovat. Je to však jen výčet, který rozhodně není vyčerpávající. 


\section{Pomůcky a student se zrakovým postižením na vysoké škole}

Pro běžný každodenní život studenta se zrakovým postižením jsou nezbytně nutné nejen podpůrné služby, pomoc pedagoga či studijního asistenta, ale také pomůcky. Dle stupně zrakového postižení je zpravidla student vybaven vlastními pomůckami, které využívá pravidelně nebo každý den, at již pro sebeobsluhu, prostorovou orientaci, nebo studium. Také CPSSP UPOL nabízí v př́ipadě potřeby možnost vypůjčení pomůcek, a to zejména $\mathrm{v}$ prrípadech plnění zkoušek, státních závěrečných zkoušek, pro přednášky, cvičení či praxe.

Výpůjčka může být užitečná rovněž v situaci, kdy student pomůcku zapomene doma nebo se mu poškodí. Například student C. nechal ve vlaku bílou hůl, Centrum mu na potřebnou dobu pomůcku pro orientaci vypůjěilo. Podobně též v prípadě, kdy se studentovi K. porouchal počítač, Centrum reagovalo na vzniklou situaci vypůjčením. Kromě počítačů je další poměrně častou službou vypůjčení diktafonu pro zvukový záznam přednášek. Mimo zmíněných pomůcek však může pracoviště nabídnout rovněž braillský řádek, televizní kamerovou lupu, mapy, plány, texty (ve zvětšeném černotisku nebo Braillově písmu). Níže si ukážeme jednotlivé pomůcky, které mohou naši studenti se zrakovým postižením využívat, a s nimiž se tak může vyučující, studijní asistent či jiný pracovník při práci s naší cílovou skupinou setkat.

\subsection{Tyflopomůcky, tyflotechnika, asistivní technologie}

V českém prostředí se pro označení pomůcky pro jedince se zrakovým postižením používá pojem tyflopomůcky, tyflotechnika. Tyflotechnika je soubor přístrojů, zařízení a pomůcek umožňujících osobám se zrakovým postižením do jisté míry kompenzovat chybějící zrakovou percepci (Hanáková a kol., 2012). Tyflotechnika slouží k odstranění, zmírnění a překonání následků zrakového postižení a usnadňuje integraci jedince se zrakovým postižením do pracovního a společenského života intaktní společnosti (Kimplová, 2010). 
V zahraničí, především $\mathrm{v}$ anglicky mluvících zemích, je používán pojem asistivní technologie (assistive technology, assistive technologies). Český jazyk většinou odkazuje na jednotlivé kategorie a skupiny asistivních technologií, jako například speciálně upravené počítače, kompenzační pomůcky, orientační a navigační systémy, přičemž v obecné rovině se pojmu téměř vyhýbá. V oblasti zrakového postižení termín asistivní technologie spojuje výhradně s oblastí speciálních informačních technologií, což je pojetí omezující a nepřesné (Seifert, 2014). Např́iklad univerzita ve státě Illinois v USA (University Library, University of Illinois Board of Trustees, 2019) zahrnuje do asistivních technologií pomůcky od bílé hole přes vodicího psa až po speciální software či pomůcky technického charakteru. Asistivní technologie pak dělí na „high tech“ a „low tech“, což volně přeloženo znamená vysoce technické a nízko technické. Naproti tomu Královský národní institut nevidomých (Royal National Institute of Blind People, 2019) hovoří primárně o spojení asistivní technologie s př́stupností technického charakteru, například přístupností počítače nebo tištěných dokumentů. Seifert (2014) upozorňuje, že by se dalo polemizovat, zda nejpoužívanější pomůcka nevidomého, bílá hůl, není asistivní technologií. Autor (tamtéž) však odpovídá jednoznačným ne, a to hned z několika důvodů - při konstrukci bílých holí musí být dodržen poměrně přísný technologický postup, ale hůl je pasivním prvkem. Aktivním prvkem je stále chodec, který získává informace o prostoru. Bílá hůl ovšem může asistivní technologii obsahovat, pokud je vybavena třeba povelovým vysílačem, laserovým modulem a jiným zařízením, které uživateli aktivně poskytuje specifickou zpětnou vazbu, a ovlivňuje tak jeho rozhodování.

Ještě než se dostaneme k výčtu tyflotechniky, uvedeme si základní rozdělení pomůcek. Sjednocená organizace nevidomých a slabozrakých (SONS, 2019) dělí pomůcky podle oblasti, v níž se využívají:

a) Pomůcky pro domácnost.

b) Pomůcky pro odstraňování informační bariéry.

c) Pomůcky pro usnadnění orientace a komunikace.

d) Pomůcky pro výuku a propagaci.

e) Pomůcky pro zábavu a poučení.

Ke konkrétnímu výčtu pomůcek pak dále řadí: elektronické pomůcky, diktafony a radiomagnetofony, hmatové knihy a pohádky, hry a hračky, hodin- 
ky a budíky, optické pomůcky, pomůcky signalizující nevidomého, slepecké hole, pomůcky pro psaní a označování, telefony a př́slušenství, a ostatní pomůcky.

Hledisek, jakými se můžeme na pomůcky a jejich rozdělení dívat, je samozřejmě celá řada. Mohli bychom pomůcky rozdělit na optické a neoptické; moderní, elektronické a klasické apod. Výše uvedené členění však poukazuje na důležitost pomůcek v jednotlivých oblastech života, při studiu i ve volném čase. Dále si uvedeme pomůcky podle jednotlivých oblastí jejich využitelnosti.

\subsection{Ukázka vybraných tyflopomůcek a jejich využití}

V následující podkapitole si uvedeme ukázku vybraných pomůcek z různých oblastí života jedince se zrakovým postižením. Čtenář může pomůcku vidět na obrázku a zároveň si přečíst základní informace včetně kontextu použití v rámci CPSSP UPOL či z pohledu potřeb studenta se zrakovým postižením na vysoké škole.

Když si laická veřejnost vybaví jedince s nevidomostí, pak mnohým lidem často vytane na mysl právě obraz člověka s bílou holí. Bílá hůl je asi nejběžnější klasickou pomůckou a využívají ji osoby s nevidomostí, se zbytky zraku, ale také slabozrací. Přesto lze konstatovat, že právě u studentů se slabozrakostí se mnohdy setkáváme s tendencí nošení bílé hole se vyhýbat. Ačkoliv tomu tak není u všech těchto jedinců, určitá část slabozrakých se přece jen nošení bílé hole snaží vyhnout. Důvody jsou různé, někdy je to spoléhání na zachovalý zrak, jindy touha nebýt označen jako osoba se zrakovým postižením. V př́padě, že se stane, že student svou hůl poškodí, zapomene ji ve vlaku apod., mưže si na vyžádání od vysokoškolského centra dočasně bílou hůl vypůjčit. Př́padně může využít služeb jiných organizací pro zrakově postižené uživatele $\mathrm{v}$ daném studijním městě. 


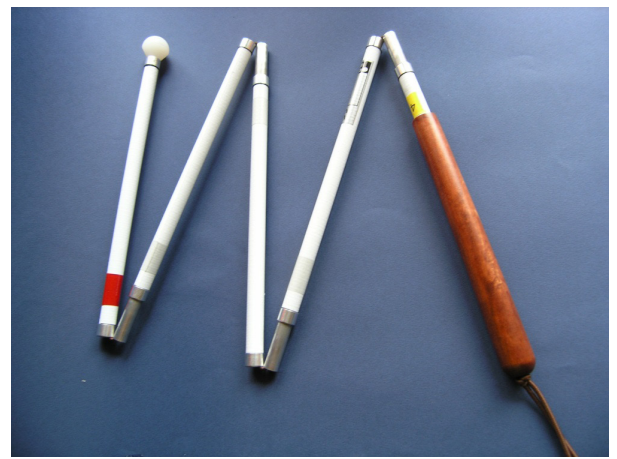

Obrázek 1: Bílá hůl (Bubeníčková, Karásek, Pavlíček, 2012)

Kromě bílé hole je ještě jeden symbol nevidomých, který si nejeden intaktní člověk vybaví - vodicí pes. Spolu s bílou holí může být vodicí pes pro nevidomého studenta velkým pomocníkem v prostorové orientaci a samostatném pohybu. Vodicí pes má samozrejmě povolen vstup jak do budovy školy či univerzity, tak do menzy, na kolej, do knihovny, zkrátka všude tam, kam se jedinec s nevidomostí potřebuje bezpečně dostat. Vysokoškolské centrum však může studentovi vlastní univerzity, je-li majitelem vodicího psa, pomoci s trasováním v rámci míst studia. Je tedy spíše na volbě studenta, zda využije služeb vysokoškolského centra nebo jiné organizace pro nevidomé v místě studia (např. Tyfloservisu, o. p. s.).

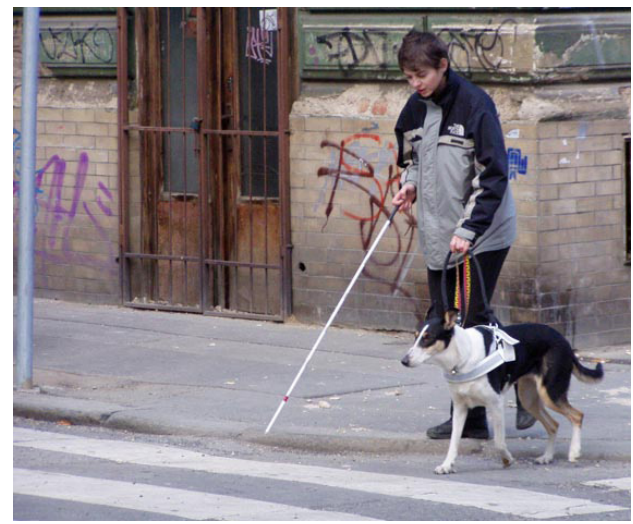

Obrázek 2: Vodicí pes (Cz-pes [online] [cit. 15. 5. 2019].

Dostupné z: http://www.cz-pes.cz) 
Další pomůckou, která je poměrně hojně využívána v rámci studia, je diktafon. Diktafon umožňuje studentovi nahrát si přednášku vyučujícího a dále s ní pracovat. Může si záznam stáhnout do počítače, případně si ho může nechat přepsat. Někteří studenti diktafon pro studium využívají hojně. Jiným studentům hlasová nahrávka v rámci učení nevyhovuje; jedná se spíše o studenty se slabozrakostí, u kterých je ještě preferována vizuální cesta zapamatování si učební látky. Diktafon si mohou studenti zpravidla od podpůrného centra na omezenou dobu vypůjčit (výpůjčky jsou samozřejmě řádně evidovány). Podobně jako diktafon, tak i mobilní telefon se speciálním softwarem může posloužit $\mathrm{k}$ nahrávce přednášky. Záleží tedy na samotném studentovi, jakou $\mathrm{z}$ pomůcek zvolí. Obyčejně mobilní telefon se speciálním softwarem (zvětšeným prostředím či ozvučením) student vlastní a využívá ke komunikaci i ke studiu.

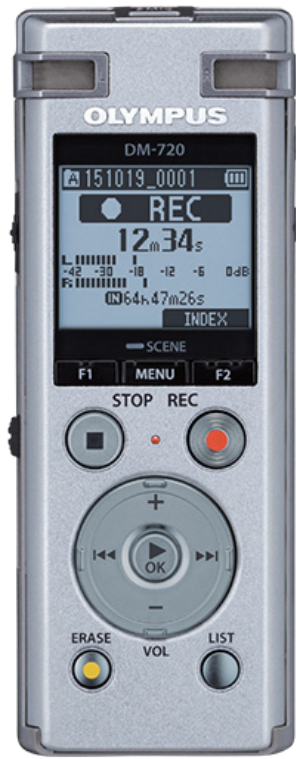

Obrázek 3: Diktafon (olympus.cz [online] [cit. 15. 5. 2019].

Dostupné z: https://www.olympus.cz) 


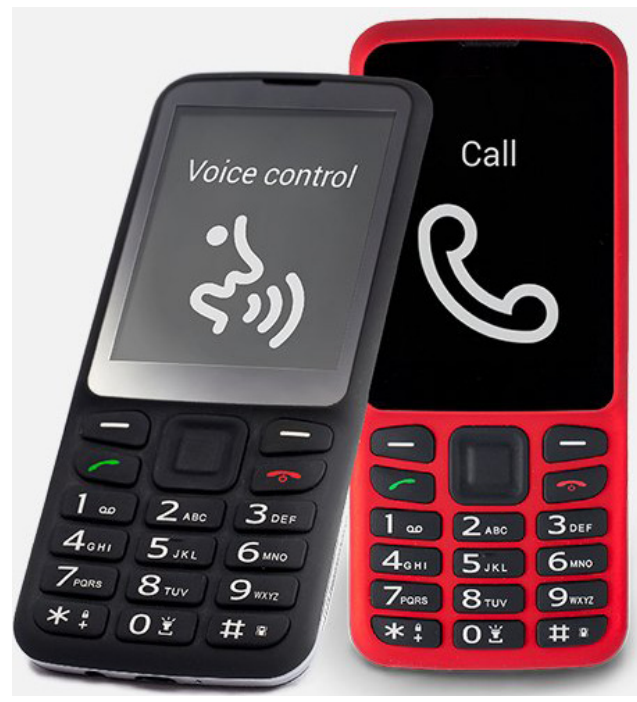

Obrázek 4: Mobilní telefon pro nevidomé (Visonia.cz. [online] [cit. 15. 5. 2019]. Dostupné z: https://www.visonia.cz/)

Pro studenta se slabozrakostí je kromě příruční lupy a telefonu se zvětšeným prostředím mnohdy nápomocná také televizní kamerová lupa. Vzhledem k její velikosti a váze se obvykle nepřenáší. Připomíná skutečně televizní obrazovku doplněnou čtecím pultem a kamerou snímající předlohu, která je pak promítána na obrazovku. Pokud student tuto lupu nemá k dispozici doma, může po domluvě využít televizní kamerové lupy umístěné v Centru. Primárně slouží právě studentům univerzity pro čtení a studium. Část studentů se zrakovým postižením ráda vystřídá práci na počítači právě čtením skrze televizní kamerovou lupu. 


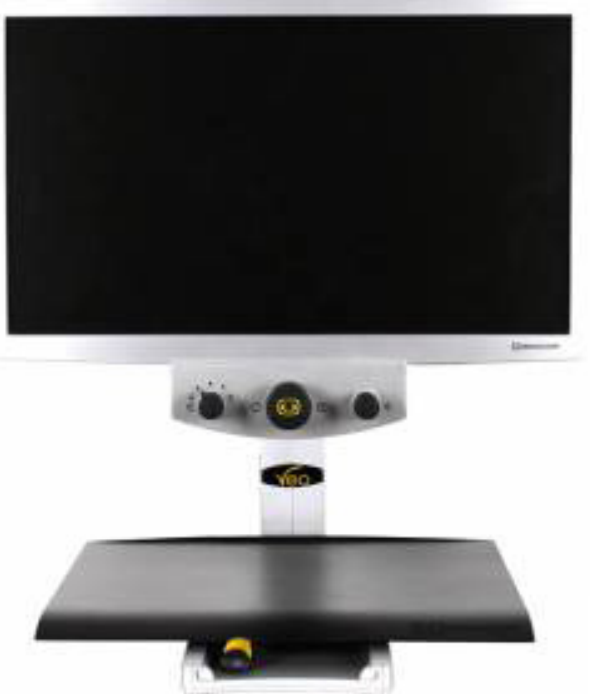

Obrázek 5: Televizní kamerová lupa (http://www.unioptik.cz [online] [cit. 29. 5. 2019])

Další pomůckou, snad jednou z nejdůležitějších pro studium na vysoké škole, je počítač se speciálním softwarem (zvětšeným prostředím či ozvučením). Lze tedy hovořit o hlasových syntézách, odečítačích obrazovky (JAWS, NVDA) a softwarových lupách (zvětšovací program MAGic, ZoomText, SuperNova).

Úprava se netýká jen softwarového prostředí, ale také hardwarového vybavení. K počítači či notebooku lze dále připojit braillský řádek, jako je například Focus 40, PAC Mate (Bubeníčková, Karásek, Pavlíček, 2012). Braillský řádek nevidomému studentovi prakticky nahrazuje obrazovku, respektive, co se zobrazuje na monitoru, to může student odečítat v Braillově písmu z braillského řádku (viz obrázek 7). 


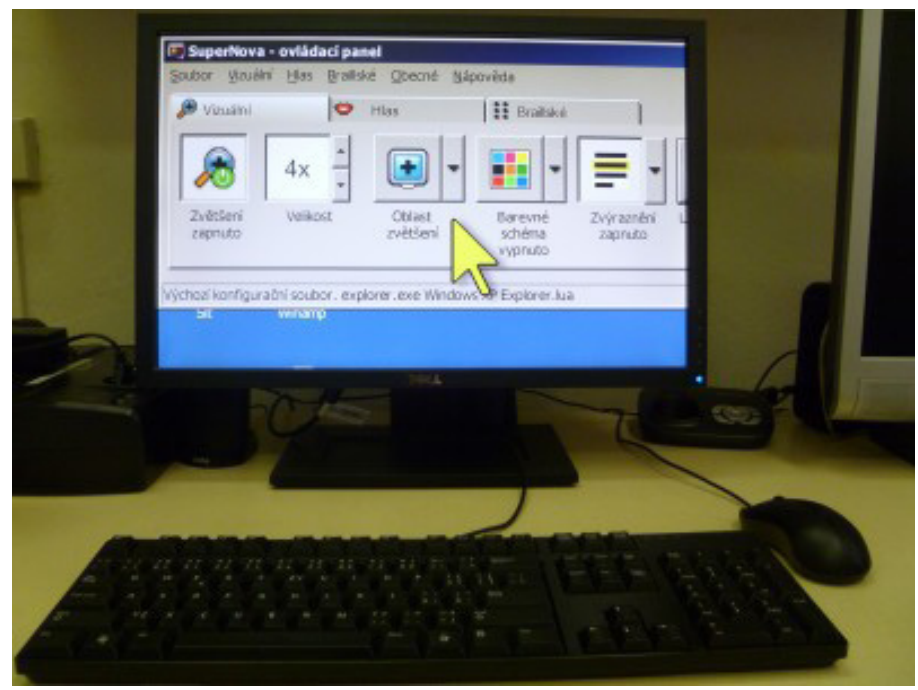

Obrázek 6: Digitální čtecí zařízení s programem SuperNova (Bubeníčková, Karásek, Pavlíček, 2012)

Notebook se speciálním softwarem či braillský řádek si mohou studenti se zrakovým postižením pořídit za podpory příspěvku na zvláštní pomůcku. Obyčejně tak právě tímto vybavením již sami studenti disponují. Nicméně pokud student přichází o zrak postupně či úrazem, může centrum zajistit na přechodnou dobu výpůjčku notebooku a braillského řádku.

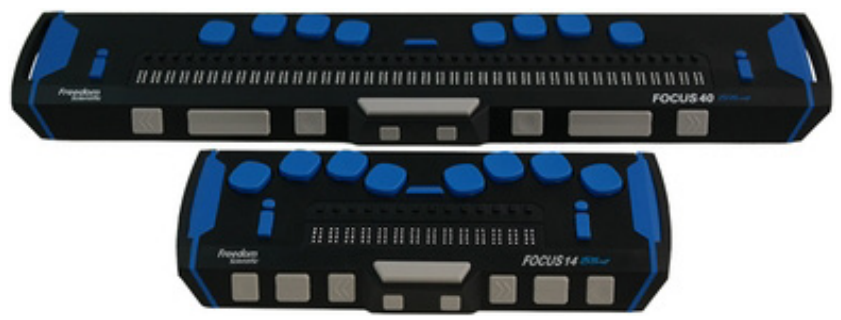

Obrázek 7: Braillský rádek (www.galo.cz [online] [cit. 29. 5. 2019]) 
Naproti tomu braillská tiskárna (př. Index Everest) již většinou není běžnou výbavou domácnosti nevidomého jedince, a reliéfní tisk je tak zadáván jiným institucím (Tyflocentrum, o. p. s., vysokoškolská střediska, KTN). V rámci CPSSP UPOL máme braillskou tiskárnu k dispozici pro tvorbu textů v Braillově písmu, primárně pro potřeby našich studentů a jejich studia obecně (zkoušky, přijímací rízení, učební texty).

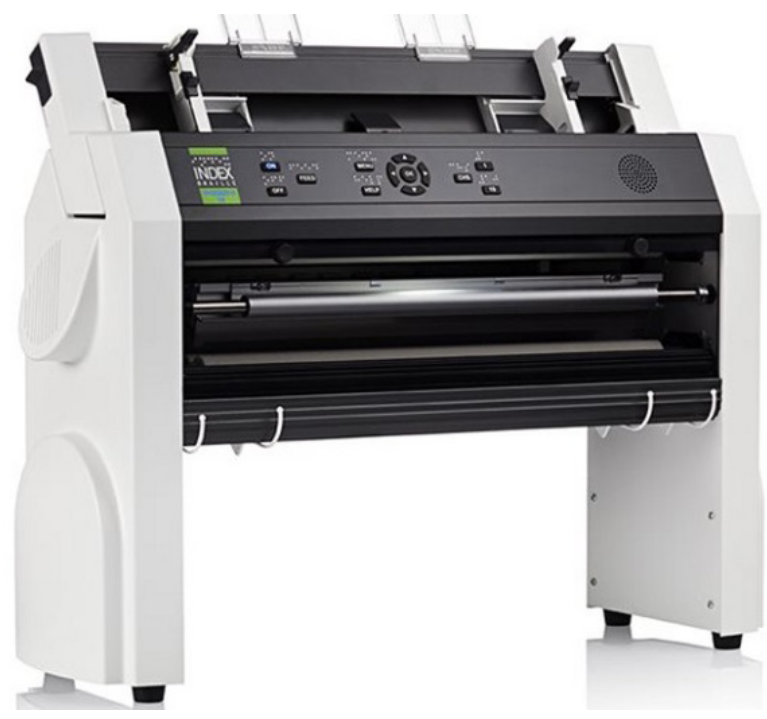

Obrázek 8: Braillská tiskárna Index Everest (https://spektra.eu [online] [cit. 29. 5. 2019])

Podobně důležité je vybavení pro tvorbu reliéfní grafiky, které vysokoškolským střediskům pomáhá vhodně doplnit braillský tisk. Užitečným nástrojem pro tvorbu reliéfních obrázků je například tiskárna reliéfních obrázků Fuser nebo P.I.A.F, 3D tiskárna např́klad od Josefa Průši (https://spektra.eu [online] [cit. 29. 5. 2019]; https://www.prusa3d.cz/ [online] [cit. 29. 5. 2019]). 


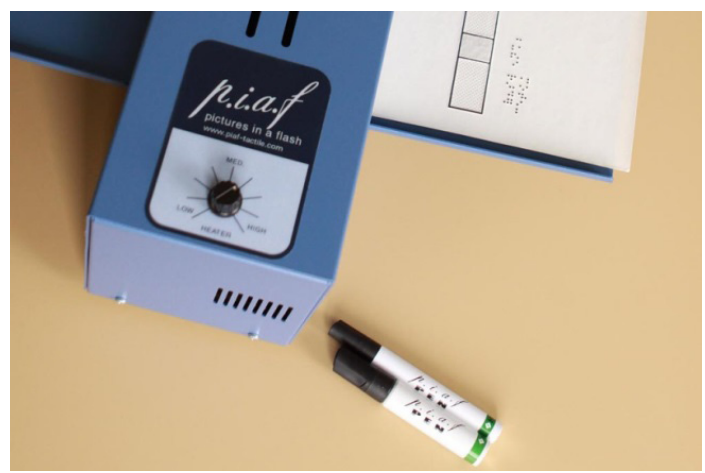

Obrázek 9: Fuzér pro výrobu reliéfních obrázků (https://spektra.eu [online] [cit. 29. 5. 2019])

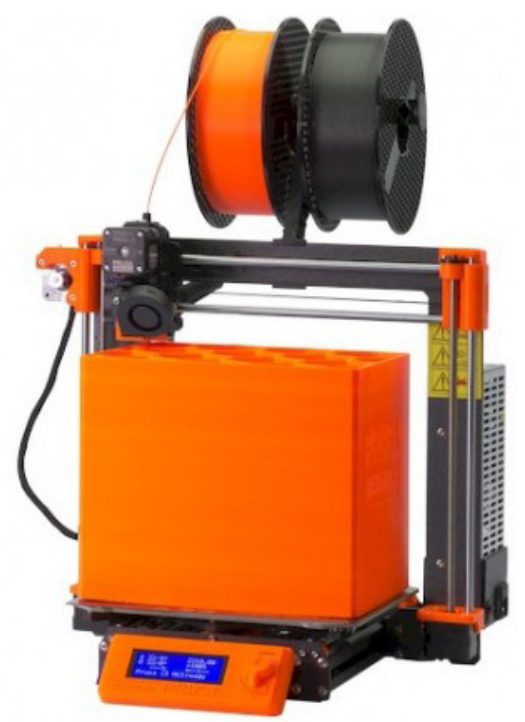

Obrázek 10: Original Prusa i3 MK3S - 3D tiskárna (https://www.prusa3d.cz/ [online] [cit. 29. 5. 2019])

Zmíněné pomůcky technického charakteru nejsou jedinými, které mohou studentovi se zrakovým postižením zjednodušit život na vysoké škole. Mohli bychom dále jmenovat různé technické novinky - aplikace do mobilního telefonu pro rozpoznávání bankovek Cash Reader, ruční čtečka pro 
nevidomé s hlasovým výstupem Orcam MyEye (Hyaku s. r. o., 2018; Galop, 2019). Našli bychom také celou řadu pomůcek tzv. klasických, kterými jsme se na tomto místě nezabývali podrobněji; tímto můžeme odkázat na příslušnou literaturu zabývající se přímo pomůckami pro osoby se zrakovým postižením.

Pro studenta vysoké školy jsou pomůcky na jedné straně důležité pro běžný každodenní život, sebeobsluhu, stejně tak jako pro prostorovou orientaci a samostatný pohyb, na druhé straně však především pro studium samotné. 


\section{Digitalizace a zpř́ístupnění textů pro studenty se zrakovým postižením}

Služba digitalizace byla v souvislosti s knihovními katalogy ve stručnosti popsána již dříve $\mathrm{v}$ textu. Na tomto místě si přiblížíme digitalizaci coby službu obecně, proces digitalizace knih a roli pracovníka pro digitalizaci dokumentů pro uživatele se zrakovým postižením.

Ze širšího úhlu pohledu zpřístupnění studijních materiálů pro studenty se zrakovým postižením zahrnuje:

a) Převod formátů PDF a PowerPointových prezentací do požadované podoby (elektronické či tištěné).

b) Přípravu digitálních dokumentů/knih (digitalizace textů).

c) Převod černotiskové předlohy studijního textu či knihy do Braillova písma.

d) Přepis zvukového záznamu přednášky, cvičení, semináře, konzultace s vyučujícím do elektronické podoby.

e) Zvětšení textu či knihy dle požadavku studenta v tištěné podobě.

f) Modifikaci studijních materiálů do reliéfní taktilní podoby, tvorbu reliéfní grafiky, 3D tisk.

g) Př́padně další úpravy podle individuálních požadavků studenta.

Z užšího hlediska se jedná o převedení běžně dostupných tištěných textů, knih a jiných studijních materiálů do digitální podoby tak, aby byl text použitelný pro odečítač obrazovky, speciální software pro uživatele se zrakovým postižením.

\subsection{Služba digitalizace v rámci institucí}

Služba digitalizace pro osoby se zrakovým postižením v České republice je poskytována některými knihovnami pro uživatele se zrakovým postižením, Tyflocentrem, o. p. s., vysokoškolskými centry či střredisky, případně organizacemi pro osoby se zrakovým postižením, většinou z nestátního sektoru. 
Např́klad Tyflocentrum, Brno, o. p. s., na svých stránkách prezentuje nabídku v následující podobě (http://www.centrumpronevidome.cz/cpi/digitalizace [online] [cit. 29. 3. 2019]):

a) Digitalizaci, tedy převod tištěných textů do textové podoby txt a word provádí jen v malém rozsahu.

b) Nedigitalizují celé knihy, učebnice, náročné texty s matematickými nebo chemickými značkami, tabulky v textu, dvojjazyčné a cizojazyčné texty nebo texty s nestandardními znaky, s potřebou náročných úprav, nákresy gramatické syntaxe, grafy apod.

c) Braillský tisk.

d) Tisk na speciální reliéfní tiskárně Fuser (včetně dodávky speciálního papíru).

Knihovna digitálních dokumentů Sjednocené organizace nevidomých a slabozrakých (zkráceně KDD SONS) se vymezuje zpřístupněním tištěných knih, časopisů a textů pro potřeby osob se zrakovým postižením. Pro klienty jsou texty dostupné ke stažení v tzv. prostém textu digitálního dokumentu. Knihovna tedy obsahuje již hotové texty v přístupné podobě pro odečítač obrazovky uživatele se zrakovým postižením (https://www.kdd.cz/ index.php?page=informace [online] [cit. 29. 3. 2019]).

Kromě zmíněné organizace nabízí Knihovna K. E. Macana v Praze časopisy, bodové knihy na prodej a vede digitální internetovou knihovnu. Vedle výpůjček poskytuje rovněž služby spojené s úpravou knih a dalších materiálů do přístupné podoby, a to nejen elektronické, tištěné, ale také zvukové (https://www.ktn.cz/cenik [online] [cit. 29. 3. 2019]):

a) Převod z analogových zvukových nahrávek do formátu MP3.

b) Individuální přepisy textů do Braillova písma: učebnice a cizojazyčné texty, tisk u již přepsaných textů, korektura, individuální přepisy not do Braillova notopisu.

c) Vazby na zakázku, xerokopie.

d) Půjčování bodových i zvukových knih osobně i poštou je zdarma.

Mezi univerzitními centry je Teiresiás, Středisko pro pomoc studentům se specifickými potřebami, de facto největším zařízením vysokoškolského charakteru v České republice. V rámci adaptace textů pro studenty se zrakovým postižením má zařazeno tyto položky:

a) Výpůjční služby a digitalizace.

b) Tisk v bodovém písmu, výroba hmatové grafiky. 
c) Výroba orientačního značení pro nevidomé.

d) Gravírování, reprografické služby.

Digitalizační servis je podstatnou součástí služeb poskytovaných Knihovním a vydavatelským oddělením Střediska Teiresiás, čímž představuje nejdůležitější způsob akvizice knihovního fondu. Slouží primárně k uspokojování studijních nároků interních studentů Masarykovy univerzity. Přesto vzhledem ke skutečnosti, že je výsledek každé digitalizace archivován $\mathrm{v}$ univerzitní knihovně pro studenty se specifickými nároky, jsou digitalizované texty následně $\mathrm{k}$ dispozici i registrovaným čtenářmu externím. Tímto způsobem fungují také další vysokoškolská zařízení, která digitalizaci textů provádějí, např.: Carolina, středisko digitalizace studijních zdrojů Informačního, poradenského a sociálního centra, Univerzita Karlova v Praze; Středisko Augustin, Univerzita Hradec Králové; Digitální knihovna - Dokumenty pro studenty se specifickými potřebami, VUT v Brně; Centrum podpory studentů se specifickými potřebami, Jihočeská univerzita v Českých Budějovicích a jiné (https://www.teiresias.muni.cz/ cz/knihovna-a-vydavatelstvi/sluzby [online] [cit. 29. 3. 2019]).

V Centru podpory studentů se specifickými potřebami UPOL je služba digitalizace určena primárně pro klienty centra, a je tak poskytována zdarma v rámci zpř́ístupnění podmínek ke studiu. Přesto si službu dle platného ceníku může vyžádat také instituce či jedinec se zrakovým postižením, který není studentem Univerzity Palackého a uživatelem centra. Aktuální ceník k datu vydání publikace pro klienty mimo domácí organizaci je uveden níže:

a) Braillský tisk A4, při dodání papíru: $15 \mathrm{Kč} /$ list.

b) Braillský tisk A4, při nedodání papíru: 18 Kč/list.

c) Braillský tisk A4, více než 100 listů při dodání papíru: 12 Kč/list.

d) Braillský tisk A4, více než 100 listů při nedodání papíru: 14 Kč/list.

e) Úprava dokumentu před speciálním tiskem, práce (tisk a kompletace $\mathrm{v}$ řádech jednotek hodin): $150 \mathrm{Kč} /$ hodinu; každá další půlhodina práce: 60 Kč; první hodina práce se účtuje vždy celá.

f) Úprava po braillském tisku - Vazba (přední a zadní list, rozebíratelné kroužky): $14 \mathrm{Kč} /$ sešit.

g) Braillský tisk na dymopásku: 5 Kč/1 znak.

h) Reliéfní tisk na tiskárně Fuser - 1 ks A4: 50 Kč/list. 
i) Digitalizace: Náklady se odvíjejí od typu dokumentu, jeho složitosti a kvality zdroje, pohybují se v rozmezí od 10 do 50 Kč za normovanou stranu (1 800 znaků).

Jak můžeme vidět z výčtu uvedených organizací, služba digitalizace a zpřístupnění dokumentů pro studenty se zrakovým postižením má v rámci domácího prostředí ČR svou sít, která se snaží pokrýt požadavky klientů.

\subsection{Specifikace digitalizovaného textu a legislativa}

Digitalizovaná kniha není přepisem předlohy či její kopií. Jedná se o adaptovaný dokument, který je určen jen pro studijní čtenáře se zrakovým postižením. Kniha nesmí být šiřena za komerčními účely, nesmí být prodávána, slouží pouze pro potřeby studenta se zrakovým postižením. Údaj o zpracování knihy je sdílen v rámci specifických knihoven (knihovní katalog pro zrakově postižené uživatele).

Z pohledu legislativy je Digitální knihovna sbírkou elektronických dokumentů zpř́stupňovaných prostřednictvím www, přičemž může uchovávat textové informace, obrazové materiály, zvukové nahrávky, video, filmy, báze dat, software, trojrozměrné objekty. Právní rovina digitalizovaných knih pro zrakově postižené uživatele vychází například z Listiny základních práv a svobod, a to konkrétně $\mathrm{z}$ následujícího obsahu:

a) Právo člověka na edukaci a práva osob s postižením.

b) Čl. 29: (2) Mladiství a osoby zdravotně postižené mají právo na zvláštní ochranu v pracovních vztazích a na pomoc při prípravě k povolání.

c) Čl. 33: (1) Každý má právo na vzdělání. Školní docházka je povinná po dobu, kterou stanoví zákon.

Dále se Listina základních práv EU zmiňuje skrze článek 26 o uznání opatření a práv osob se zdravotním postižením k zajištění jejich nezávislosti, sociálního a profesního začlenění, včetně účasti na životě společnosti.

Mimo jiné se k danému vztahuje legislativa týkající se knihovní činnosti, zákon č. 37/1995 Sb., o neperiodických publikacích, ve znění pozdějších předpisů. Také zákon č. 35/1965 Sb., o dílech literárních, vědeckých a uměleckých (autorský zákon), ve znění pozdějších předpisů, v paragrafu 15 (2, písm. k) hovoří následovně: „Autorovo svolení k užití díla nepotřebuje 
a odměnu není povinen poskytnout, kdo rozmnoží vydané dílo zvláštní technikou pro potřeby nevidomých. "Celkově je klíčovým legislativním aspektem zajistit právo na vzdělání cílové skupiny.

\subsection{Proces digitalizace textů pro studenty se zrakovým postižením}

Služba digitalizace začíná vždy požadavkem od studenta se zrakovým postižením. Obvykle na začátku semestru, př́ípadně v průběhu roku podle požadavků vyučujících, předkládá seznam knih, o které má zájem.

V první řadě koordinující pracovník pro digitalizaci vyhledá, zda je některá z požadovaných knih v České republice již zpracována (viz již zmíněný katalog Daleth). Je-li zpracována, odkazuje pracovník na danou instituci, kde si student může text vyžádat. Zbytek knih, které nikde zpracovány nejsou, se digitalizuje.

Cílem služby je adaptace předlohy do př́stupné podoby při zachování co největší informační hodnoty předlohy. Pracovník pracující na digitalizaci prochází předlohu a odhaduje náročnost textu vzhledem ke kvalitě původního textu. Následuje skenování předlohy (pořízení digitálních snímků stránek knih pomocí skeneru). Dalším krokem je získat z těchto snímků takový text, který je odečítačem zpracovatelný a $\mathrm{v}$ první řadě počítačem upravitelný, a to nejlépe v textovém dokumentu (Word). Zmíněná operace je provedena počítačovým programem (např. FineReader), který provede optické rozpoznávání znaků (Optical Character Recognition, OCR). Program rozpoznává písmena a jiné znaky z pořízených snímků. Právě proto, že rozpoznávání znaků není vždy bezchybné, zbývající chyby se musí opravit ručně v textovém editoru. Například v některých případech jsou písmena „rn“ programem rozpoznána jako graficky podobné písmeno „m“. Po hrubé úpravě je text připraven pro detailnější korektury. Po úvodních úpravách se pak vytvářejí dvě základní podoby textů, a to jak pro nevidomé se speciálními značkami pro usnadnění orientace v textu speciálním softwarem, tak ve zvětšené podobě pro slabozraké.

Nevidomý uživatel textu zpravidla používá odečítač obrazovky (NVDA, Jaws aj.), který mu knihu přečte v audiopodobě. Co se týká samotné úpravy 
textu do adaptované podoby, tak tato zahrnuje: označení nadpisů příslušnou značkou a stylem; vložení formátovaného textu do značek, které odečítač čtenáři přečte (např́ílad vymezení začátku a konce textu psaného tučně speciálními značkami); popsání obrázků slovy; přidání komentářů editora u komplikovaných nebo nesrozumitelných částí; všechny použité značky jsou vysvětleny na začátku dokumentu v rámci průvodky dokumentem; pod průvodkou jsou umístěny bibliografické údaje a obsah vygenerovaný z nadpisů. Více viz dále citovaná metodika (Metodika k úpravám elektronických textů pro zrakově postižené čtenáře, Teiresiás, 2014).

Slabozraký uživatel pracuje se zvětšeným digitálním dokumentem většinou v počítači se speciálním softwarem (např. ZoomText), kde si může dále přizpůsobit zvětšení, kontrast, barevnost textu apod. Přesto se v rámci adaptace dokumentů provádí výše zmíněné úpravy, s tím rozdílem, že nejsou použity všechny speciální značky jako pro nevidomé uživatele, nebot slabozrakého uživatele mohou naopak při čtení vizuálně rušit. Použity jsou primárně značky $\mathrm{k}$ označení nadpisů pro snazší orientaci v počítači. Jinak úpravy zahrnují zvětšení písma do nadstandardní velikosti, zvětšení rozestupů mezi rádky, nastavení bezpatkového písma (např́klad Arial). Obrázky nejsou vkládány př́mo do dokumentu, ale je na ně odkazováno, čímž si uživatel může obrázek otevřít v obrázkovém prohlížeči a pohodlně zvětšovat.

Lze vytvořit také tzv. univerzální podobu dokumentu, v níž jsou sloučeny některé prvky vhodné jak pro slabozraké, tak pro nevidomé uživatele. Podle požadavku je třeba se do jisté míry přizpơsobit přání uživatele textu.

Jak již bylo uvedeno výše, při přípravě digitálního dokumentu pro zrakově postižené uživatele je dodržována speciální metodika - metodika k úpravám elektronických textů pro zrakově postižené čtenáře. Materiál si neklade za cíl stanovit vyčerpávající pravidla, která se při úpravách textů pro potřeby zrakově postižených čtenářů mají provádět. Každý nový text s sebou potenciálně nese další specifika, jejichž zohlednění vyžaduje individuální přístup a prŕípadně nová řešení. Metodika shrnuje principy, jichž se při zpracovávání elektronických textů drží pracovníci střediska Teiresiás, nabízí zkušenosti získané v této oblasti opřené o zpětnou vazbu samotných čtenářơ (Teiresiás, 2014). Také CPSSP UPOL se řídí zmíněnou metodikou s ohledem na individuální požadavky uživatele digitálního dokumentu se zrakovým postižením. Konkrétní úpravy jsou uvedeny v samostatném textu. 


\subsection{Pracovník pro digitalizaci a předpoklady pro výkon činnosti}

V rámci této podkapitoly se zmíníme o pracovníkovi, který koordinuje digitalizaci, a o samotném asistentovi pro digitalizaci, který primárně provádí přímou úpravu textů. Vyjádříme se $\mathrm{k}$ předpokladům pro výkon zmíněných pozic, bude se jednat spíše o náš subjektivní pohled na věc.

\subsubsection{Pracovník koordinující digitalizaci, náplň práce a předpoklady pro výkon profese}

Pracovník, který v rámci CPSSP UPOL koordinuje digitalizaci knih pro zrakově postižené uživatele, v sobě spojuje znalosti technického charakteru a předpoklady pro práci $\mathrm{v}$ rámci pomáhající profese.

Z pohledu náplně práce se kromě úprav textů pracovník zabývá také jinými činnostmi souvisejícími s prrístupností studijních materiálů, a proto by měl mít kromě osobnostních kvalit též technické znalosti, být ochoten stále se učit či spolupracovat s kolegy technického zaměření. K výčtu vykonávaných činností pracovníka můžeme zařadit:

a) Digitalizace knih a elektronických dokumentů do různých podob (univerzální použití, použití pro slabozraké, digitalizace testů (zkoušky, přijímací zkoušky), předzpracování (vypůjčení, skenování, OCR).

b) Koordinace práce směrem $\mathrm{k}$ asistentům digitalizace, kontrola dokumentů zpracovaných asistenty, zaškolování nových pracovníků pro digitalizaci, pomoc s řešením problémů s digitalizací pro asistenty.

c) Práce s tyflografikou k doplnění digitalizovaného textu či k samostatnému studiu - tisk materiálů v Braillově písmu, výroba hmatových map.

d) Pracovník se zapojuje do prrímé práce s klienty, a to nejen při domluvě požadovaných titulů $\mathrm{k}$ digitalizaci, ale např́klad také v rámci studijní asistence či technické podpory (při výuce, u zkoušky, státní závěrečné zkoušky, promoce).

e) Částečně technická povaha pozice s sebou nese nutnost orientovat se v moderních technických pomůckách pro cílovou skupinu. Náplň práce se pak může dotýkat aktualizací, vyladění přístrojů po softwarové a někdy i hardwarové stránce, at již jde o braillskou tiskárnu, počítač se speciálním softwarem, braillský rádek, či zvětšovací lupu aj. 
Z pohledu předpokladů pro výkon této pomáhající profese bychom mohli zmínit následující (upraveno dle Úlehla, 2005; Matoušek, 2003; Kopřiva, 1997):

a) Zdatnost a inteligence: podpora a pomoc $v$ rámci digitalizace předpokládá vynaložení značného množství energie, proto je velmi důležité umět hospodařit se silami, udržovat se v dobré tělesné kondici a žít zdravým životním stylem. Samotný kontakt s klienty, domluva zakázky a konečná práce na textech předpokládá, že si pracovník umí rozložit síly. Podstatná je přirozená inteligence, průběžná práce na osobním i profesním růstu skrze studium aktuálních novinek a literatury, účast na semináríích, kurzech.

b) Důvěryhodnost: uživatel na pracovníkovi vnímá smysl pro čestnost, jeho sociální roli, otevřenost, nízkou motivaci pro osobní prospěch. K danému se pojí diskrétnost, zachování mlčenlivosti, spolehlivost, porozumění. Zdrojem důvěryhodnosti je rovněž fyzický vzhled, upravenost, ale i celková pověst a chování, vystupování pracovníka.

c) Komunikační dovednosti: v neposlední řadě je podstatné, aby pracovník pro digitalizaci uměl využívat komunikační strategie a komunikovat jako profesionál, měl by být schopen naslouchat, projevit empatii (nikoliv lítost), vytyčit si hranice, pokud se klient chová nevhodně nebo požaduje po pracovníkovi něco, co není v popisu jeho služeb. Ke komunikačním dovednostem bychom zde mohli zařadit také elektronickou komunikaci s asistenty, kteří digitalizují texty, a s klienty, pro něž jsou dokumenty určeny.

Kromě uvedených předpokladů by měl pracovník koordinující digitalizaci, tedy také asistenty, kteří texty upravují, umět celý proces rozdělení práce řídit. Měl by tedy mít určité organizační schopnosti. Měl by být rovněž schopen upozornit vhodným způsobem na chyby, kterých se asistenti v rámci úprav textů dopustí. Dále s nimi totiž komunikuje o jejich úpravě až do té fáze, kdy je text připraven pro zavěšení na knihovnu. $V$ prrípadě potřeby provádí finální úpravy textů sám, záleží na pokročilosti a zkušenostech asistenta pro digitalizaci.

Stává se, že se požadavků na texty v určitém období nahromadí více, což vyžaduje od koordinujícího pracovníka pro digitalizaci schopnost vypořádat se se stresem a tedy určitou míru frustrační tolerance a po omezené období zvládat zvýšený stres. V neposlední řadě by měl být pracovník flexibilní, 
měl by být schopen přizpůsobit se změnám, at již se týkají požadavků klientů, doporučení vedoucího pracovníka, či ochoty dále se vzdělávat, účastnit se akcí edukačního charakteru (konference, přednášky, setkání kolegů aj.).

Charakterově a temperamentem by pracovník neměl být vyhraněným introvertem, ale spíše se pohybovat někde ve středu mezi extroverzí a introverzí. Povaha práce totiž vyžaduje jak prrímý kontakt s klienty, tak práci o samotě př̀ úpravě textů.

\subsubsection{Asistent pro digitalizaci textů pro zrakově postižené uživatele}

Pracovník, který provádí prímou práci s textem, připravuje knihu do přístupné podoby, nedomlouvá zakázku a nemusí tedy vůbec přijít s klientem do kontaktu. Není zde tedy vyžadována určitá temperamentově vymezená povaha, tak jako u jeho vedoucího kolegy. Je však možné, že vyhraněného extroverta nemusí práce na textech nutně bavit vzhledem k tomu, že se jedná čistě o práci o samotě. Stejně tak z našich zkušeností vychází poznatek, že tato práce nemusí být vhodná pro jedince se specifickými poruchami učení nebo pro osoby, které nejsou laděny na detail (perfekcionismus). Důslednost je v této práci totiž poměrně dosti podstatná, včetně dodržení metodiky a korekce vlastních chyb. Stejně tak nemusí být pozice vhodná pro povahy výrazně kreativní, které nepreferují práci dle striktně stanovených pravidel, ale naopak vyhledávají činnosti kreativní, kde mají vysokou míru svobody.

Povaha práce asistenta pro digitalizaci je založena na práci v prostředí počítače, od skenování po úpravu ve FineReaderu a konečnou úpravu v textovém editoru. Měl by být tedy do jisté míry technicky zdatný v rámci běžné uživatelské obsluhy počítače. Zároveň by měl být schopen učit se novým věcem, pokud má v některé $\mathrm{z}$ oblastí úprav textů nedostatky.

Důležitou součástí je též schopnost dodat text ve stanoveném termínu, umět pracovat s časem a organizovat si jej. Přijetí kritiky ze strany korekce pracovníka koordinujícího digitalizaci je rovněž velmi podstatné. Tato pozice je vhodná jak pro studenty, tak pro osoby, které mají zkušenost s editorskou činností a úpravami textů obecně. Výhodou je, že se práce 
dá provádět odkudkoliv, tedy v rámci „home office“ (domácí kanceláře). Rozložení práce $z$ časového rámce daného termínu splnění je pak přímo na asistentovi, což skýtá flexibilní pracovní dobu.

Mezi asistenty digitalizace jsme provedli malé šetření $\mathrm{k}$ jejich pohledu na vlastní práci. Zde uvádíme některé z vybraných výpovědí:

„Mě digitalizace baví. Mohu ji dělat z vlaku nebo autobusu, když jedu ze školy a do školy. Jak mám čas mezi přednáškami, tak si třeba sednu na chodbu a dělám. Je to pro mě práce, díky níž pomáhám, a to mě těší."

"Jsem osoba se zdravotním postižením, ale pracovat na knihách $z$ domu můžu. Když jsem se dozvěděla o zapojení do digitalizací, doufala jsem, že bych mohla po delši době zase pracovat. A klaplo to!"

„Pro mě je to odpočinek. Když upravuji text, tak vím, že nemusím myslet na učení se na zkoušku nebo jiné věci. Někdy mám ze všech těch školních povinností trochu unavené oči, a tak se ke knihám ani nedostanu, ale jindy si vezmu notebook třeba ven a sednu na lavičku a prostě makám."

„Chtěla jsem si přivydělat. Nejdř́v jsem digitalizaci vzala jen z toho dưvodu, protože jsem měla práci jen na pưl úvazek, a to mě nemohlo uživit. Ǩíkala jsem si, že to bude dočasné, a ted' jsem tady už rok a doufám, že i nadále budu." 


\section{Závěr}

Hlavním posláním prezentovaného textu bylo seznámit čtenáře $s$ fungováním vysokoškolských středisek a center v kontextu klientely se zrakovým postižením. Obsahově teoretické poznatky doplňují praktické aspekty a zkušenosti z praxe.

Osoba se zrakovým postižením dospělého věku, která opouští stř̌ední vzdělávání, či dospělý, který si při zaměstnání doplňuje vzdělání, pro nás nejsou jen studenty, ale také lidmi se svými osobnostními předpoklady, specifiky i přáními. Každý člověk se zrakovým postižením by měl mít možnost zhodnotit své přednosti i limity a na základě toho vhodně volit další cestu vzdělávání. Dnes by se již na vysoké škole neměl objevit jev, který jsme mohli spatřit v minulosti, tedy chybějící podpůrné služby. Ze zákona jasně vychází povinnost zpř́stupnit člověku se zrakovým postižením vzdělávání a vytvořit takové podmínky, které jedinci umožňují plnit studijní povinnosti. Podoba podpory a pomoci může být různá co do intenzity či množství čerpaných služeb.

Pomoc poskytovaná univerzitou není jen záležitostí podpůrných středisek a jejich zaměstnanců, do celého procesu obecně vstupuje lidský faktor, pedagogové, spolužáci, pracovníci studijních oddělení a provozní zaměstnanci.

Avšak rozvoj podpůrných služeb pro studenty se zrakovým postižením v rámci vysokoškolského studia není posláním pouze školského resortu. Rovněž společnost by $\mathrm{v}$ rámci podpory vzdělanosti osob s postižením měla mít na paměti, že čím je člověk se zrakovým postižením vzdělanější, tím menší je jeho informační deficit a tím produktivnější může tento jedinec být coby člen společnosti. Zde se samozřejmě dotýkáme také palčivé otázky zaměstnanosti cílové skupiny, která by se ideálně měla s dosaženým vysokoškolským vzděláním zvyšovat.

Vysokoškolské podpůrné Centrum se mimo jiné snaží své klienty se zrakovým postižením připravit na běžný život, ne jen upravit podmínky studia. Právě samostatnost jedince, aktivní př́istup k životu a spoluutváření podpůrných služeb jsou zárukou, že se student se zrakovým postižením bude 
schopen po absolutoriu vysoké školy postavit na „vlastní nohy“. Centrum podpory studentů se zrakovým postižením UPOL ve svých klientech vidí potenciálně úspěšně socializované členy společnosti. 


\section{Reference}

BUBENÍČKOVÁ, H., KARÁSEK, P., PAVLÍČEK, R. Kompenzační pomůcky pro uživatele se zrakovým postižením. Brno: Tiskárna Helbich, 2012.

ISBN 978-80-260-1538-3.

BYTEŠNÍKOVÁ, I. Komunikace dětí předškolního věku. Praha: Grada, 2012. ISBN 978-80-247-3008-0.

DUCHOŇ, B., ŠAFRÁNKOVÁ, J. Management. Integrace tvrdých a měkkých prvků rízení. Praha: Beck, 2008. ISBN 978-80-7400-003-4.

HANÁKOVÁ, A., a kol. 1000 pojmů ze speciální pedagogiky. Olomouc:

Univerzita Palackého, 2012. ISBN 978-80-244-3218-2.

HORVÁTHOVÁ, I., PASTIERIKOVÁ, L. Inkluzivní vzdělávání na vysokých školách v České republice. Integrace a inkluze ve školní praxi. Ročník IV., č. 6, únor 2017. Praha: Forum, 2017. s. 22-28. ISSN 2336-1212.

JOYCE, C. R. B., et al. Individual Quality of Life. UK: Psychology Press, 2013. 246 s. ISBN 978-9057024245.

KIMPLOVÁ, T. Ztráta zraku: úvod do psychologické problematiky. Ostrava:

Pedagogická fakulta, Ostravská univerzita v Ostravě, 2010.

ISBN 978-80-7368-917-9.

KOPŘIVA, K. Lidský vztah jako součást profese: Psychoterapeutické kapitoly pro sociální, pedagogické a zdravotnické profese. Praha: Portál, 1997.

ISBN 80-7178-150-9.

LEŠKO, L. Náhled do sociální komunikace. Brno: Tribun EU, 2008. ISBN 978-80-7399-466-2.

MATOUŠEK, O., a kol. Metody a ř́zení sociální práce. Praha: Portál, 2003. ISBN 80-7178-548-2.

MICHALÍK, J. Zdravotní postižení a pomáhající profese. Praha: Portál, 2011. ISBN 978-80-7367-859-3.

MICHALÍK, J., HRUBEŠOVÁ, I., POSPÍŠILOVÁ, I., KARUNOVÁ, H., SILBEROVÁ, A., HAICLOVÁ, Z., MAJKUSOVÁ, E., VACHALOVÁ, V. Kvalita života osob pečujících a osob se zdravotním postižením - výzkumná šetření 2018. Olomouc: Univerzita Palackého, 2018. ISBN 978-80-244-5471-9 (v tisku).

POKORNÁ, A. Komunikace se seniory. Praha: Grada, 2010.

ISBN 978-80-247-3271-8. 
ÚLEHLA, I. Umění pomáhat: Učebnice metod sociální praxe. Praha: Slon, 2005. ISBN 80-86429-36-9.

WIKING, M. The Little Book of Hygge. UK: Penguin Books, 2016. ISBN 9780241283912.

\section{Legislativa}

EUROSKOP.CZ. 2019. Listina základních práv EU [online]. Praha: Vláda ČR, (C) 2005-2019 [cit. 29. 3. 2019]. Dostupné z: https://www.euroskop.cz/204/ sekce/listina-zakladnich-prav-eu/

MŠMT ČR. 2019. Pravidla pro poskytování príspěvku a dotací veřejným vysokým školám Ministerstvem školství, mládeže a tělovýchovy pro rok 2019. Praha: MŠMT ČR.

MŠMT ČR. 2019. Zákon č. 561/2004 Sb. o předškolním, základním, středním, vyšším odborném a jiném vzdělávání (školský zákon), ve znění pozdějšich předpisů. Praha: MŠMT ČR.

MŠMT. 2018. Analýza současné situace studentů se specifickými nároky na vysokých školách [online]. @ 2013-2018 [cit. 27. 7. 2018]. Dostupné z: http://www.msmt.cz/vzdelavani/vysoke-skolstvi/analyza-soucasne-situace-studentu-se-specifickymi-naroky-na

MŠMT. Výkonové ukazatele, F: vysoké školy [online]. @ 2013-2018 MŠMT [cit. 27. 7. 2018]. Dostupné z: http://www.msmt.cz/vzdelavani/skolstvi-v-cr/statistika-skolstvi/data-o-studentech-poprve-zapsanych-a-absolventech-vysokych POSLANECKÁ SNĚMOVNA, PARLAMENT ČR. 2019. Listina základních práv a svobod [online] Praha: Parlament České republiky, Poslanecká sněmovna [cit. 29. 3. 2019]. Dostupné z: https://www.psp.cz/docs/laws/listina.html Zákon č. 35/1965 Sb., o dílech literárních, vědeckých a uměleckých (autorský zákon), ve znění pozdějších predpisů.

Zákon č. 37/1995 Sb., o neperiodických publikacích, ve znění pozdějších př̀edpisů.

\section{Elektronické zdroje}

AP3SP. 2018. O asociaci [online]. Brno: Masarykova univerzita, 2013-2018 [cit. 5. 4. 2019]. Dostupné z: http://www.ap3sp.cz/

ELUPY.CZ. 2019. OrCam MyEye 2.0 [online]. ZAS Group s.r.o. ( ) 2010-2019 [cit. 18. 6. 2019]. Dostupné z: https://web.elupy.cz/orcam-myeye-20

HAYAKU, s. r. o. 2019. Cash Reader [online]. Cash Reader od Hayaku s. r. o., (C) 2018 [cit. 18. 6. 2019]. Dostupné z: https://cashreader.app/cs/ 
CPSSP UPOL. 2019. Studenti se zrakovým postižením [online]. Olomouc: UP [cit. 12. 2. 2019]. Dostupné z: http://cps.upol.cz/informace-pro-studenty-se-specifickymi-potrebami/studenti-se-zrakovym-postizenim/

CZ-PES. Bludička Nirreterrit - vodicí pes - po vyjití do silnice [online]. Cz-pes.cz, (C) 2001-2013 [cit. 15. 5. 2019] Dostupné z: http://www.cz-pes.cz/ obrazek-943-q-Bludicka-Nirreterrit-vodici-pes-po-vyjiti-do-silnice

ČSÚ. Vysoké školy [online]. @ 2017 [cit. 27. 7. 2018]. Dostupné z: https://www.czso.cz/documents/11292/32508276/1011_c04t44. pdf/90a075e8-7017-4313-af92-ac522e60ac27?version=1.0

DVOŘÁK, M. 2016. Škola pro výcvik vodicích psů [online]. (C) 2016 [cit. 26. 11. 2018]. Dostupné z: http://www.vycvikvodicichpsu.cz/o-nas/ desatero-pro-kontakt-s-nevidomym-ktereho-vede-vodici-pes/

EMMONS, R. A., MCCULLOUGH, M. E. 2003. Highlights from the Research Project on Gratitude and Thankfulness [online]. () 2003 [cit. 27. 7. 2018]. Dostupné z: http://www.psy.miami.edu/faculty/mmccullough/Gratitude-Related\%20Stuff/highlights_fall_2003.pdf

GALOP. 2019. Braillské rádky Focus Blue [online] GALOP, s. r. o., () 2019 [cit. 29. 5. 2019] Dostupné z: http://www.galop.cz/focus

KDD. 2019. Informace [online]. SONS ČR, z. s., () 2006-2019 [cit. 29. 3. 2019]. Dostupné z: https://www.kdd.cz/index.php?page=informace

KNT. 2019. Ceník výrobků a služeb [online]. BIBLIO, 2019 [cit. 29. 3. 2019]. Dostupné z: https://www.ktn.cz/cenik

MU. 2019. Daleth: Knihovní brána pro zrakově postižené [online]. Brno: MU, (C) 2017 [cit. 28. 2. 2019]. Dostupné z: https://www.teiresias.muni.cz/daleth/ NRZP ČR. 2006. DESATERO komunikace s pacienty se zrakovým postižením [online]. @ 2006 [cit. 27. 11. 2018]. Dostupné z: http://www.nrzp.cz/poradenstvi-sluzby/desatero-pro-komunikaci-s-ozp/352-desatero-komunikace-s-pacienty-se-zrakovym-postizenim.html

OLYMPUS.CZ. DM-720 [online]. () 2018, Olympus [cit. 15. 5. 2019]. Dostupné z: https://www.olympus.cz/site/cs/a/audio_systems/audio_recording/high_end_ recorders/dm_720/index.html

PRUSA. 2019. Prusa3D [online]. Prusa Research s. r. o., (c) 2019 [cit. 29. 5. 2019] Dostupné z: https://www.prusa3d.cz/

Royal National Institute of Blind People. 2019. Assistive technology [online]. RNIB, ๑) 2014-2019 [cit. 6. 5. 2019]. Dostupné z: https://www.rnib.org.uk/ information-everyday-living-work-and-employment-staying-work/assistive-technology 
SEIFERT, R. 2014. Termín asistivní technologie pohledem Radka Seiferta [online]. Poslepu.cz [cit. 6. 5. 2019]. Dostupné z: https://poslepu.cz/termin-asistivni-technologie-pohledem-radka-seiferta/

SONS. 2019.

SPEKTRA:EU. Braille a hmatová grafika [online]. Spektra v. d. n., (c) 2017 [cit. 29. 5. 2019] Dostupné z: https://spektra.eu/katalog-braille-a-hmatova-grafika/

TEIRESIÁS MU. 2018. Knihovna a vydavatelství [online]. Brno: Masarykova univerzita, (C) 2000-2018 [cit. 28. 2. 2019]. Dostupné z: https://www.teiresias. muni.cz/cz/knihovna-a-vydavatelstvi

TEIRESIÁS. 2014. Metodika k úpravám elektronických textů pro zrakově postižené čtenáře [online] Brno. MU, 2014 [cit. 29. 3. 2019]. Dostupné z: https://www.teiresias.muni.cz/download/Metodika_VII.pdf

TEIRESIÁS. 2018. Služby [online] Brno, MU, (c 2000-2018 [cit. 29. 3. 2019]. Dostupné z: https://www.teiresias.muni.cz/cz/knihovna-a-vydavatelstvi/sluzby

SONS. 2019. Tyflopomůcky Olomouc [online]. Software e-komerce od PrestaShop $^{\text {тM }}$ (C) 2019 [cit. 29. 3. 2019]. Dostupné z: https://www.tyflopomucky.cz/olomouc/

TyfloCentrum Brno, o. p. s., 2019. Digitalizace. [online]. (C) 2002-2019 [cit. 29. 3. 2019]. Dostupné z: http://www.centrumpronevidome.cz/cpi/ digitalizace

UNIOPTIK. 2019. Video, digitální zvětšovací televizní lupa VEO [online]. Studio DAMI, (C) 2013 [cit. 29. 5. 2019] Dostupné z: http://www.unioptik.cz/ p767/lupy/digitalni-kamerove-lupy-video-lupy-kompenzacni-pomucky-pro-slabozrake/video-digitalni-zvetsovaci-televizni-lupa-veo/

UNIVERSITY LIBRARY. 2019. Blind/Visual Impairment: Common Assistive Technologies [online]. USA: University of Illinois Board of Trustees [cit. 6. 5. 2019]. Dostupné z: https://guides.library.illinois.edu/c.php?$\mathrm{g}=526852 \& \mathrm{p}=3602299$

UPOL. 2019. Katalogy Knihovny UP [online]. Olomouc: Univerzita Palackého [cit. 12. 2. 2019]. Dostupné z: https://www.knihovna.upol.cz/katalogy/

VISONIA.CZ. Mobilní telefony pro zrakově znevýhodněné [online]. Visonia.cz, (c) 2018 [cit. 15. 5. 2019]. Dostupné z: https://www.visonia.cz/

WHO. 2004. The World Health Organization Quality of Life-BREF [online]. (C) 2004 [cit. 23. 4. 2018]. Dostupné z: http://www.who.int/mental_health/media/ en/76.pdf 


\section{KATALOGIZACE V KNIZE - NÁRODNÍ KNIHOVNA ČR}

Karunová, Hana

Podpora směřovaná studentovi se zrakovým postižením na vysoké škole / Hana Karunová. -1. vydání. - Olomouc : Univerzita Palackého v Olomouci, 2020. - 1 online zdroj

Nad názvem: Univerzita Palackého v Olomouci, Pedagogická fakulta. Obsahuje bibliografii

ISBN 978-80-244-5836-6 (online ; pdf)

* 316.344.6-056.262*378.011.3-052 *376.04*37.091.64* (048.8)

- osoby se zrakovým postižením

- vysokoškolští studenti

- speciální vzdělávací potřeby

- učební pomůcky

- monografie

376 - Výchova a vzdělávání zvláštních skupin osob [22] 
Hana Karunová

\section{Podpora směřovaná studentovi se zrakovým postižením na vysoké škole}

Výkonná redaktorka Lucie Šrammová Nguyenová Odpovědná redaktorka Barbora Vodičková Jazyková korektura Jiř́ Slavík Technická redaktorka Anna Petříková

Vydala a vytiskla Univerzita Palackého v Olomouci Kř́žkovského 8, 77147 Olomouc www.vydavatelstvi.upol.cz

1. vydání

Olomouc 2020

DOI: $10.5507 /$ up.21.24458359

ISBN 978-80-244-5835-9 (tisk)

ISBN 978-80-244-5836-6 (online: PDF)

Neprodejná publikace

VUP 2020-0306 (tisk)

VUP 2020-0307 (online: PDF) 